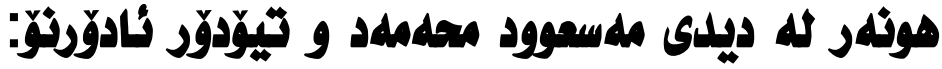 \\ تويَّرينهوويلهكى بلهراوردكاربيه
}

ذلهبلهز صمد احمد

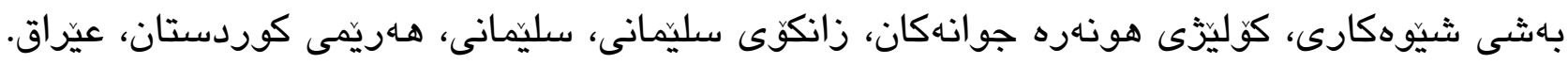
nabaz.ahmed@univsul.edu.iq ئيمهيل:

شيكارى بهراوردكارى نيّوان دوو فهيلهوف، كه سهر به دوو جوكرافيا و كوَتيكستى ميّزوويى، كؤمهلآيهتى، كولتوورى و هزرى جياوازن، ثٔهركيكى قورسـ. مـسعوود محهمهد أ فهيلهسوفى كورد و تيوّدور

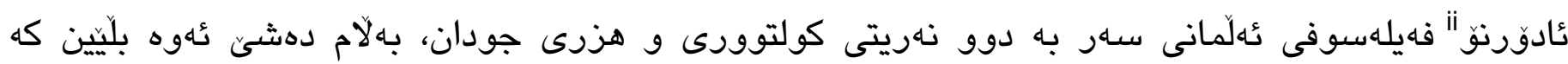
تيّزِوانينه فهلسهافى و شيكارييهكانيان بوّ هونهر و هونهرمهند له يهكدييهوه نزيكن. مـسعوود و عادورنق هـهان شت دهكهن، بهلام لهسهر دوو ئاست و كونتيكستى جياواز.

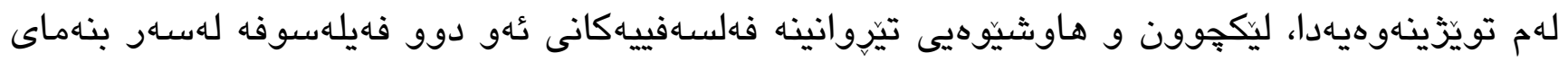

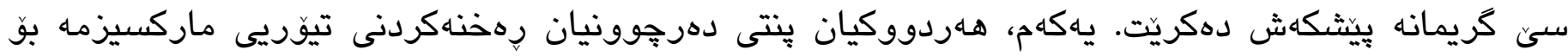

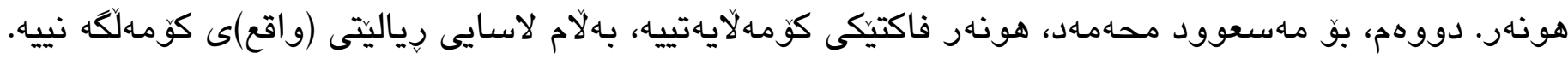

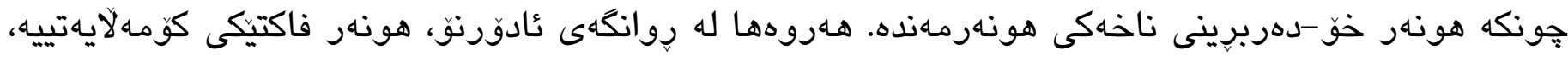

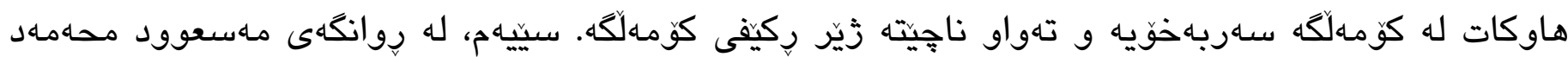

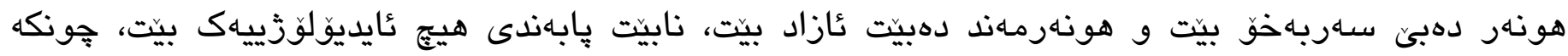

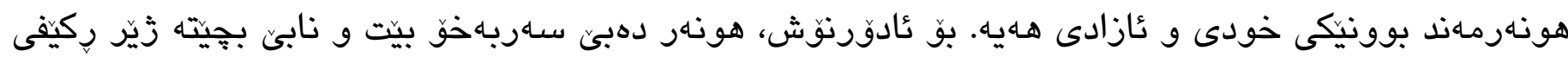

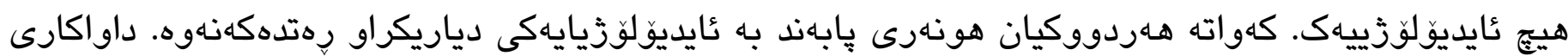

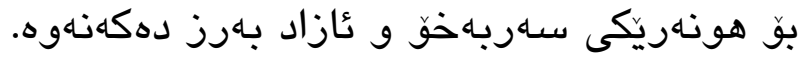

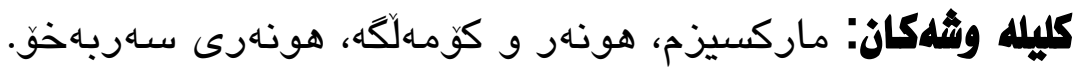




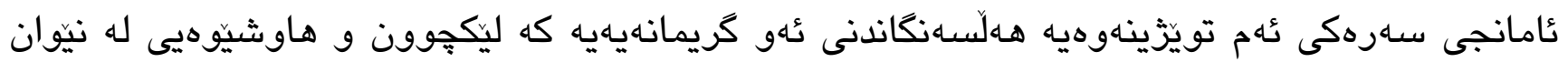

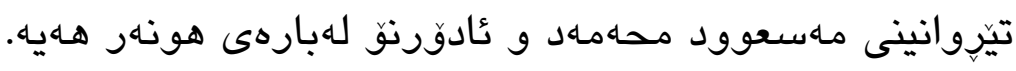

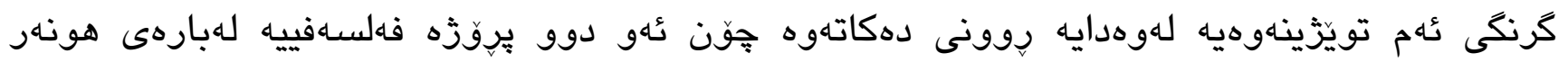

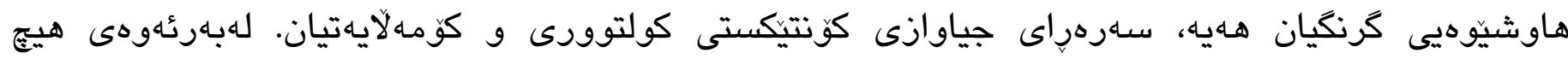

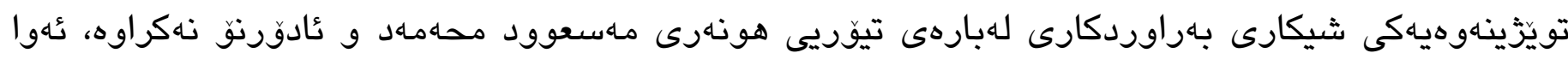

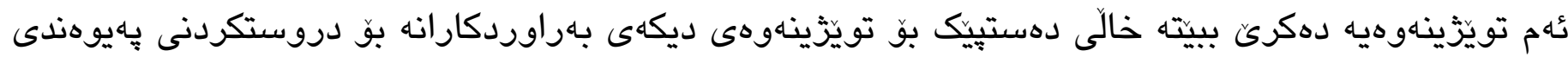
له نيّوان هزرى كوردى و فهلسهاهیى خوّرئاواييدا.

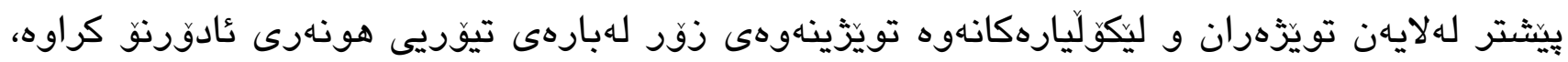

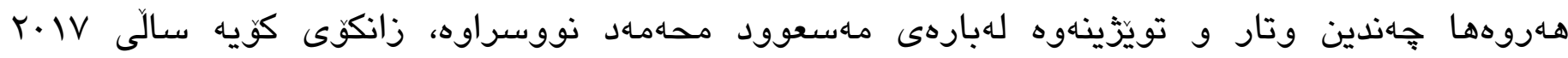

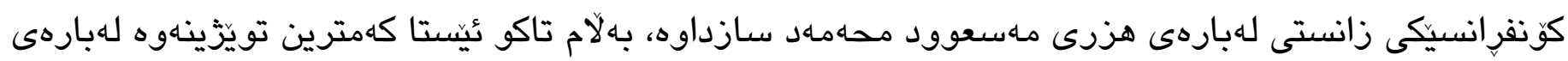

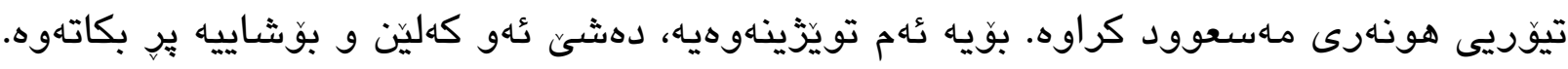

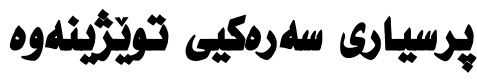

برسيارى سهرهكى ئهم تويَّينهوهيه بريتييه له: ئايا دهريّت، سهرهراى جياوازى كونتيكستى ميّزوويى

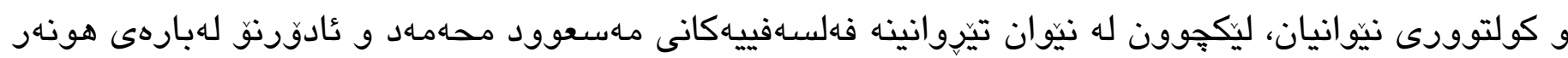

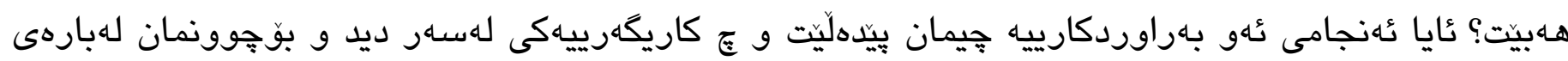

هونهرهوه دهبيت؟؟

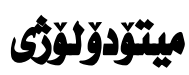

لهم تويزّينهوهيهدا ميتوّىى شيكارى بهراوردكارى (comparative analysis) بو شيكردنهوه و

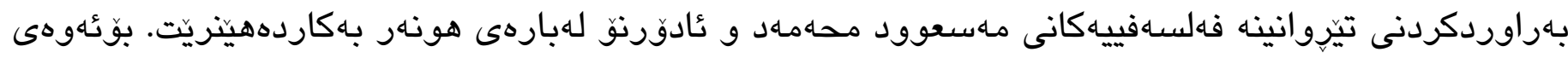

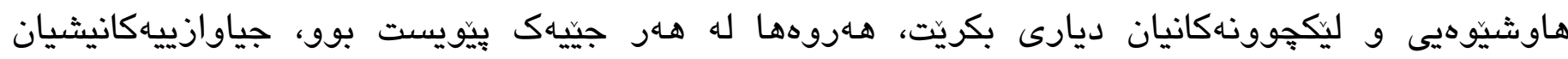
دهربخريّت.

بو ئهم تويَزينهوهيه بشت به دوو جوّر سهارجاوه دهبهستريّت: سهارهكى و لاوهكى. سهرجاوه سهرهكييهكان نووسين و ئيشه رِهسهنه فهلسهفييهكانى مهسعوود محهمهد و ئادورنق له خوّدهكرن. 


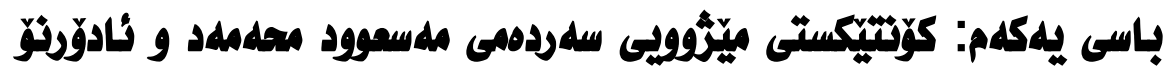

مـهعوود محهمهد سالّى 1919 له شارى كوّيه، له باشوورى كوردستان هاتوته دونيا. له شارى بهغدا

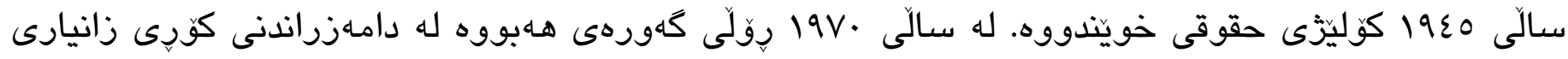

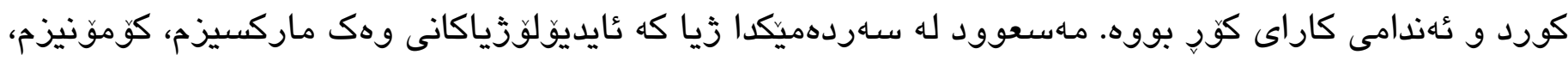

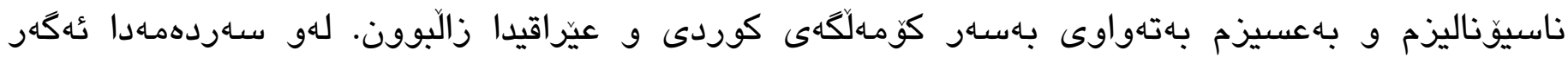

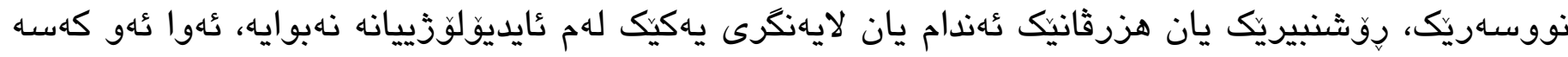

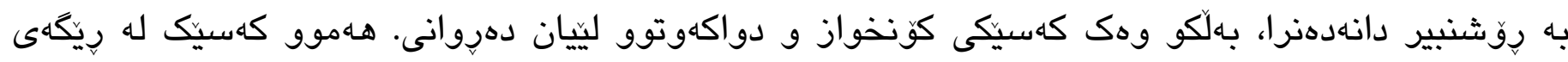

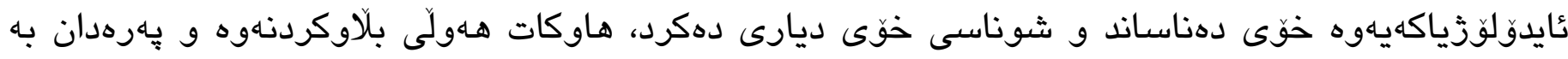

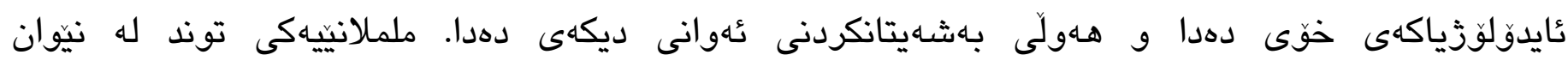

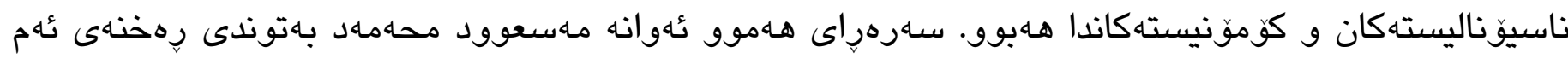

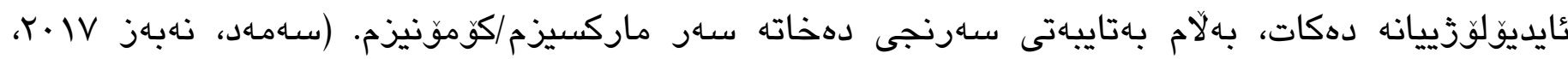
.$(Y \wedge \wedge J$

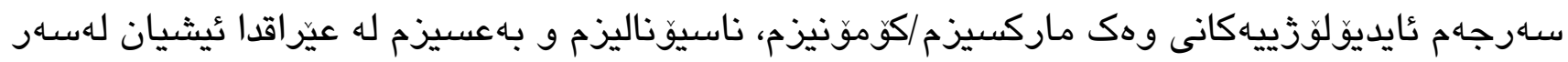

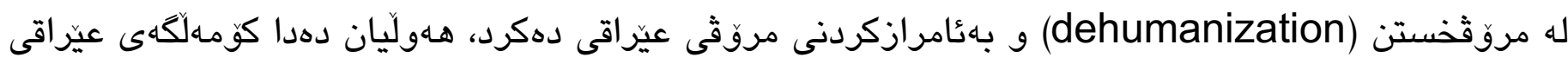

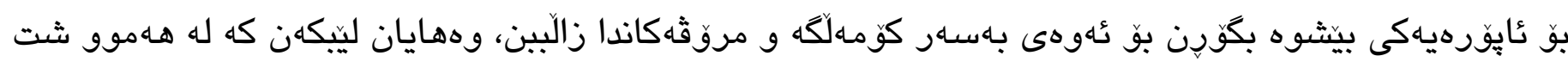

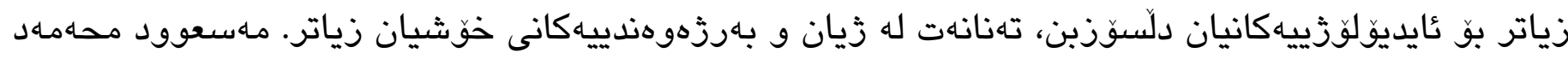

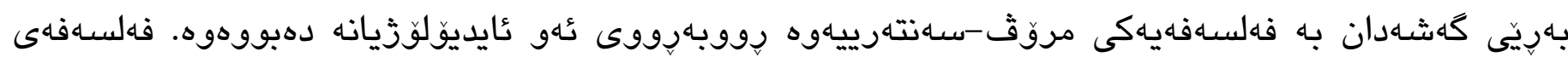

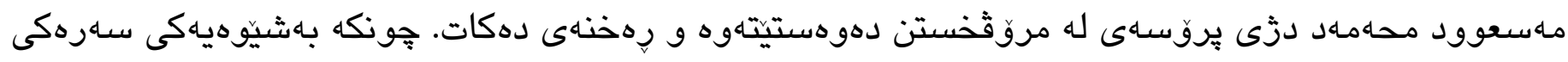

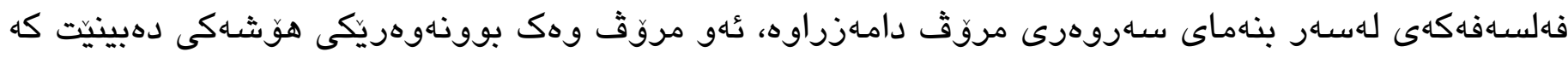

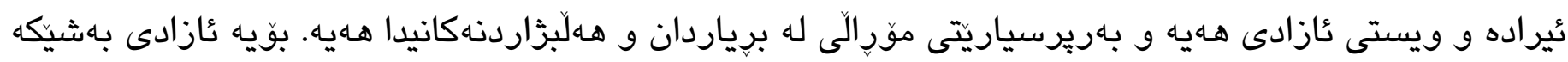

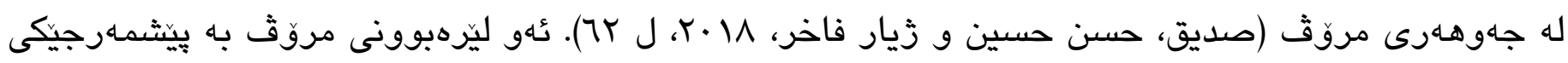

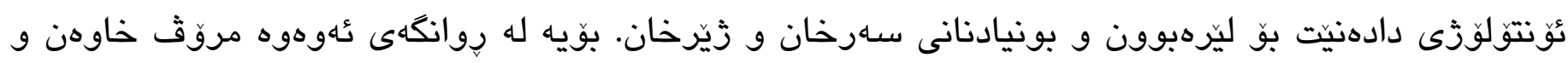

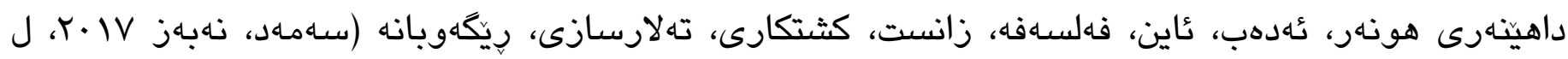

تيوّدور ئادورنوّ (r.19_1979) سهر به يهكهم ناهوهى قوتابخانهى فرانكفورته. عُهو له لايهنى باوكيهوه

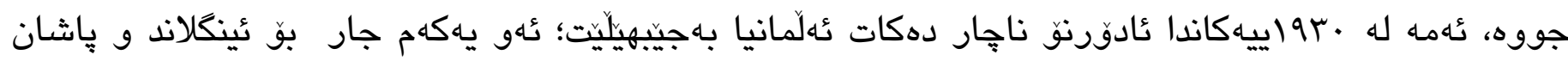

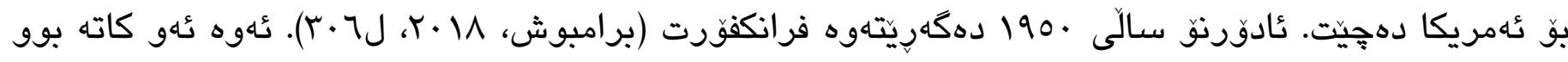
كه هوّلوّكوّست بوّ يهكهم جار بهتهواوى ناسرا بوو، هـروهها بيوو به بابهتيكى سـهرهكى لهنيو فهلسهفهكهى

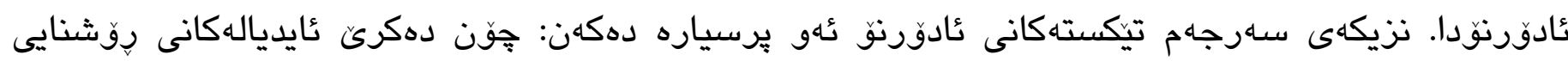




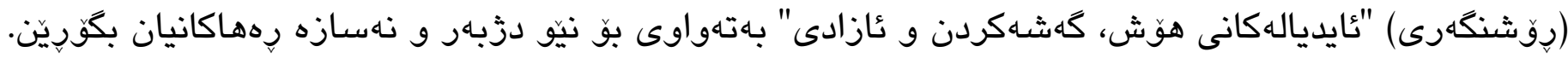

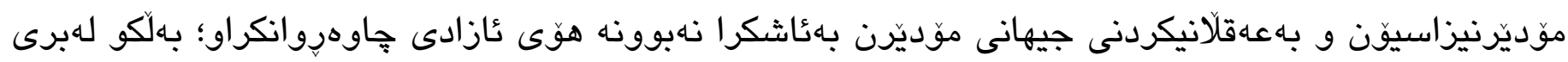

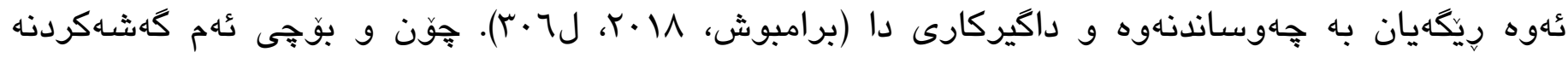

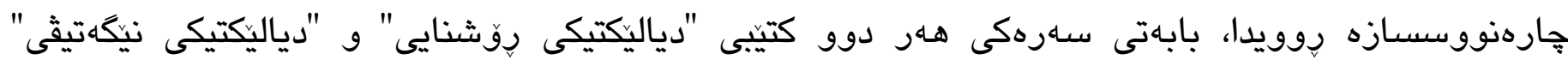

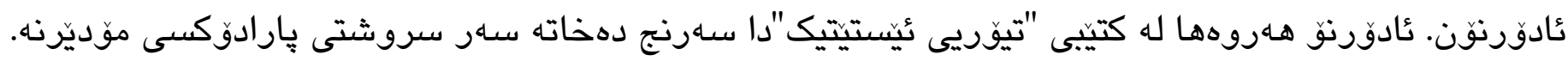

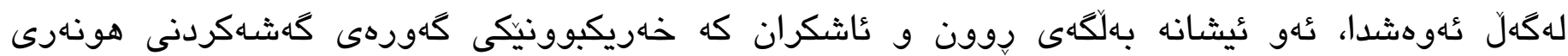

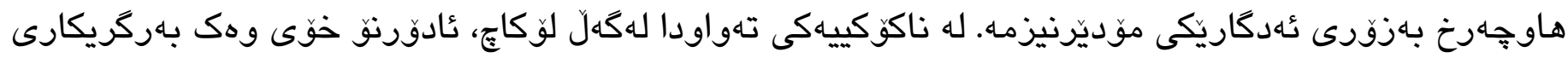

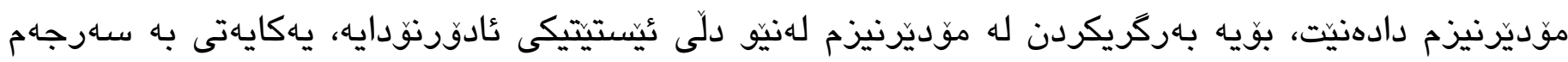

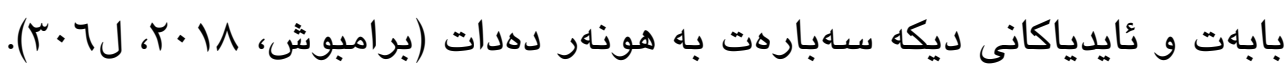

\section{باسى دووهم: تيوّرِيَ ماركسيزم بوّ هوثلهر}

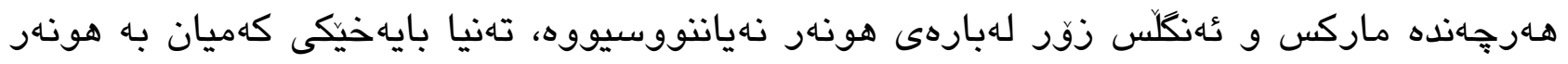

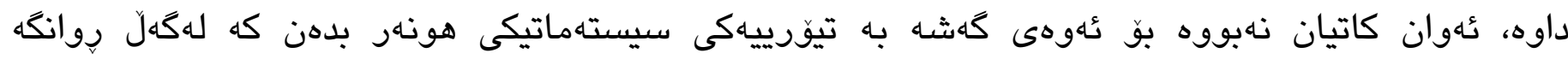

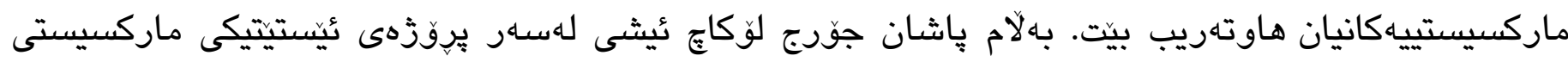

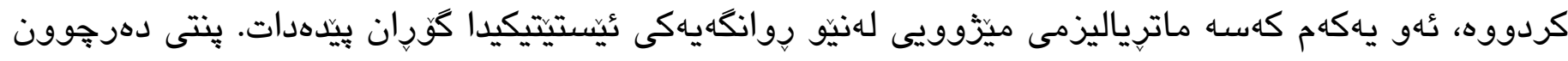

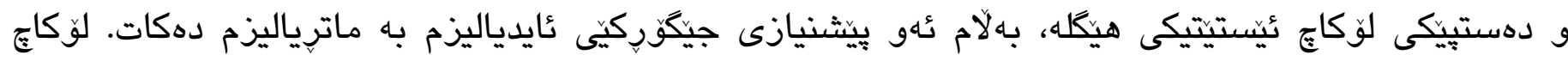

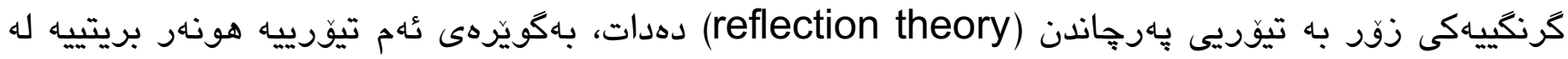

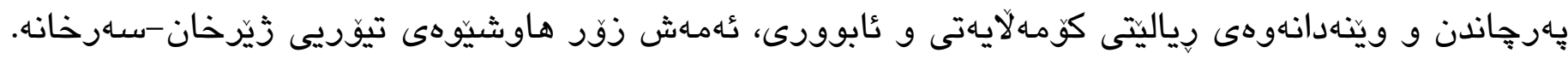

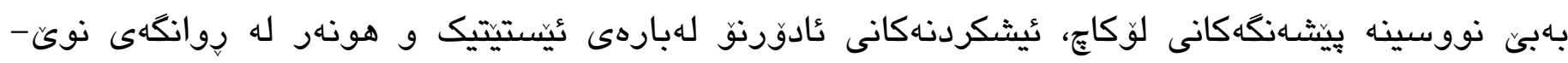

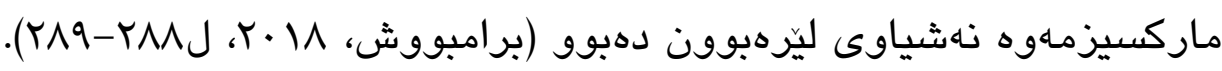

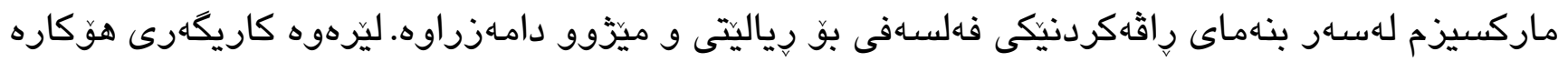

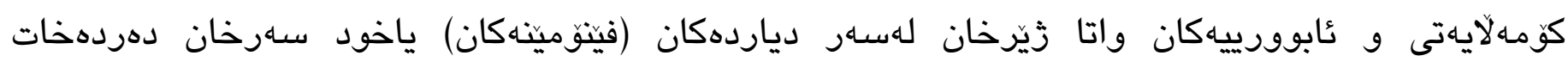

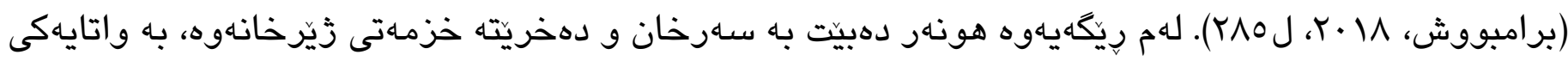

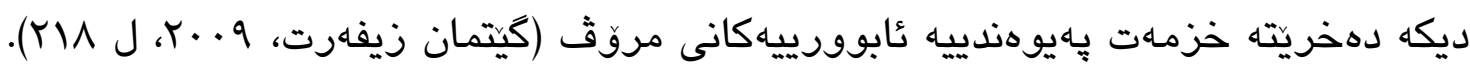
له ماركسيزمدا بهكَتى هونهر دهكريّت به عامرازيّك بوّ كهياندنى راستييه سياسييهكان به هـمووان و

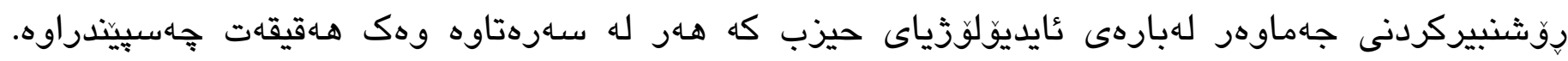

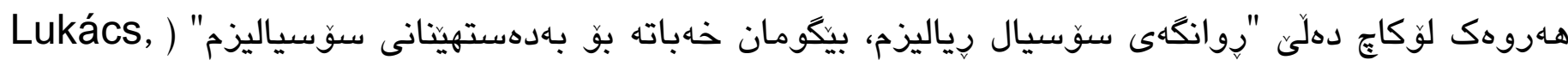

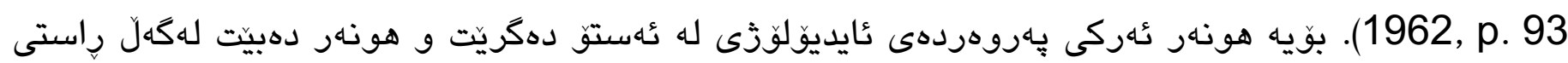




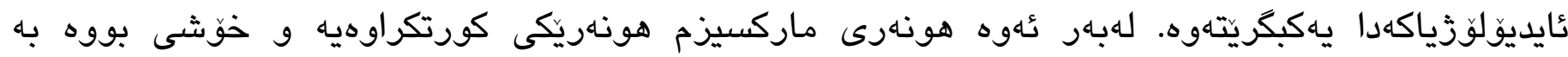

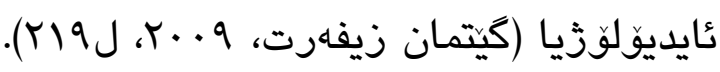

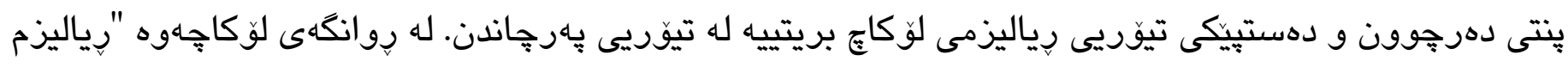

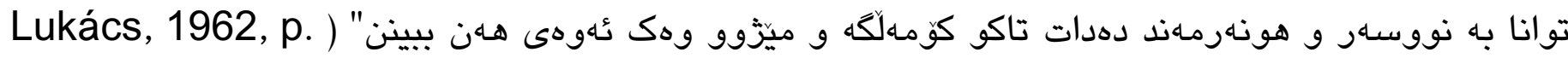

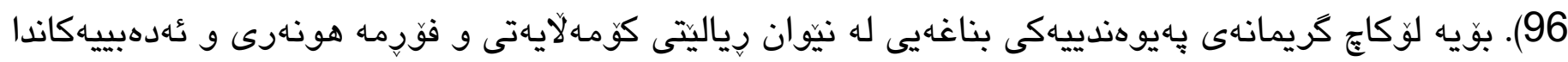

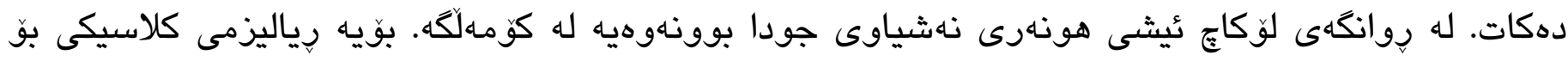

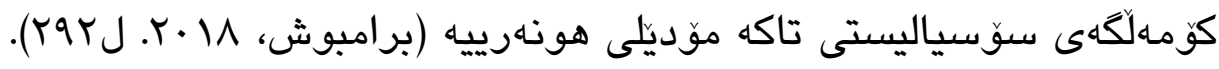

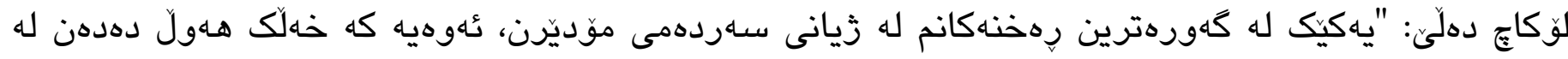

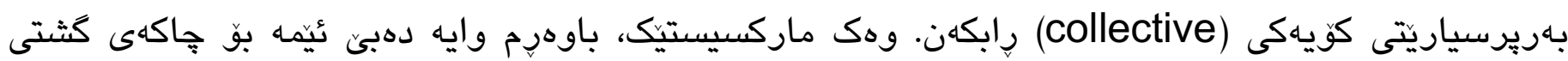

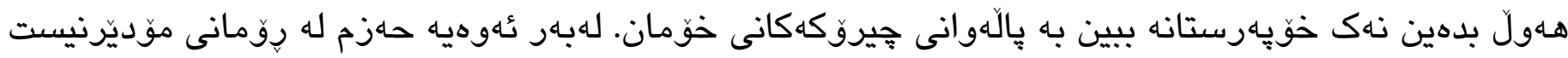
نييه. رِومانى رياليستى (واقعى) له رِومانى موّديّرنيستى بالآتره، جونكه زوّر بهسادهيى زوّر وردتر ويّنهى زيان يِيشان دهدات. رياليزم تهنيا ستايليك نييه لهناو ستايلهكانى ديكه، بهلكو بناغهى هـموو ستايلهكانى ئهدهب و هونهره" (Lukács, 1962, p. 48).

\section{باسى سيّيلم: ديلدى مdسعوود محهمهد بوّ هوذلهر و رهخنهى لله ماركسيزم}

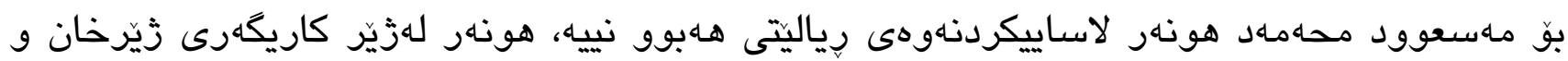

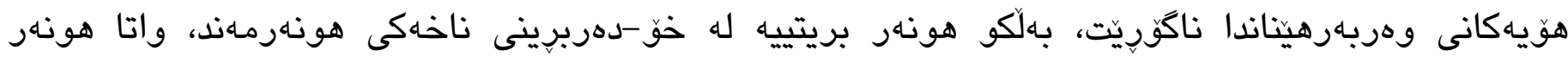
بارهـهى هوَش و دهروونى هونهرمـهنده. جونكه هونهر كويى و لاساييى داكهوت (واقع) نييه، بهلكو كُوزارشت

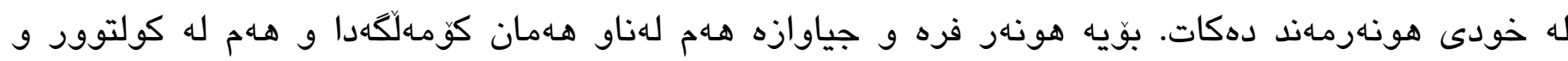

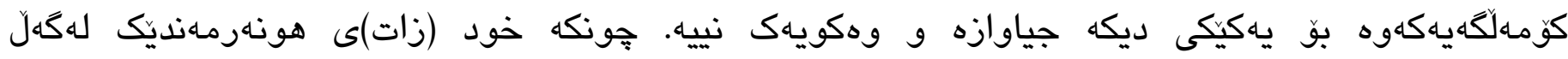

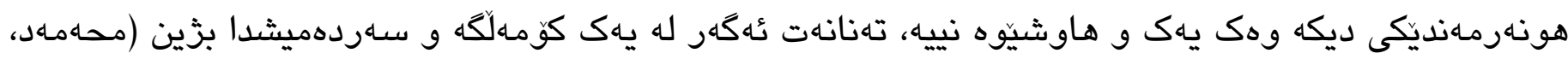

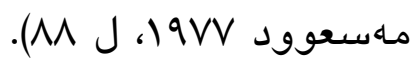

ئهميرى حهسهن يوور وهك ماركسيستيكى كورد له نامهيهكدا بو مهسعوود محهمهد لهبارهى سهارخان و

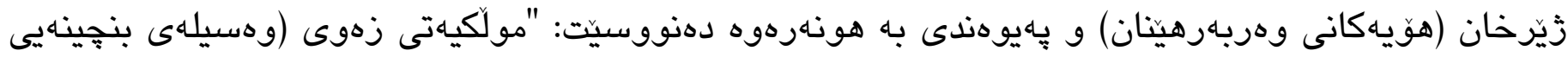

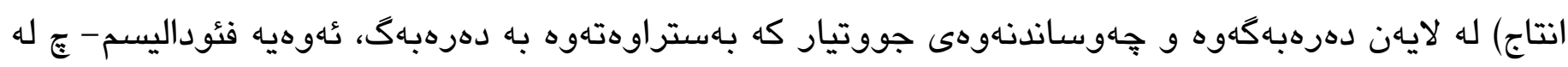
كوردستان ع له يابان و جين و هند و فهرانسه و ئينكلتهرهوه. ئهمه ماهيهته، ئهوانى تر- هونهر، ئهدهيات،

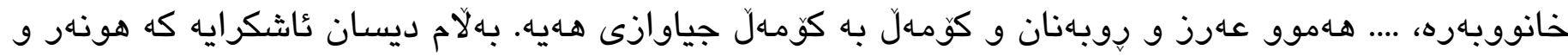


أهدهبى فئودالى فهرانسه زورتر لله هونهر و ئهدهبى فئودالى ئينكليز و يابان... نزيكتره تا له هونهر و ئهدهبى

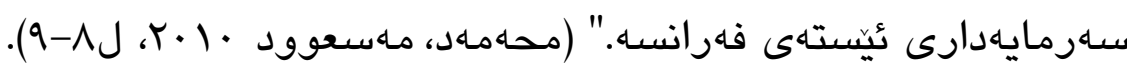

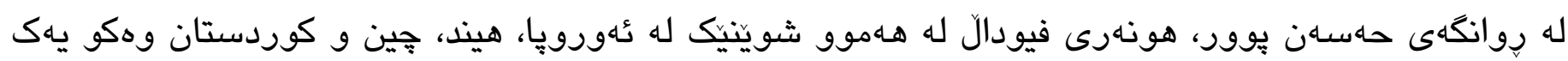
و هاوشيّوه و له يهكدييهوه نزيكه، هـروهها هونهرى سـرمايهدارييش له هـموو شوينينيك وهكو يهك و هاوشيّوهيه. هونهر و ئهدهبى فهرهنساى فيودال له ئهدهب و هونهرى زايِّنى فيودال نزيكتره تا ئهدهب و هونهرى

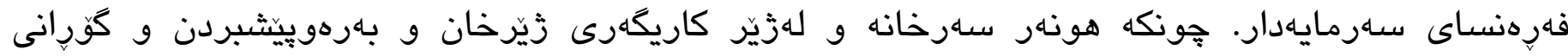

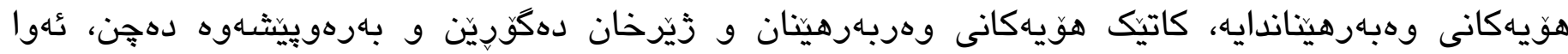
هونهاريش دهكَّريتي.

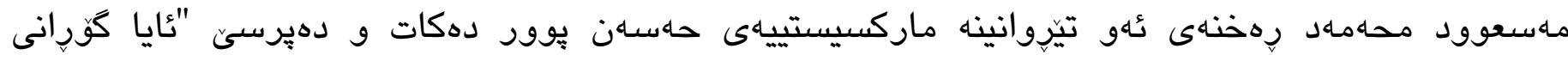

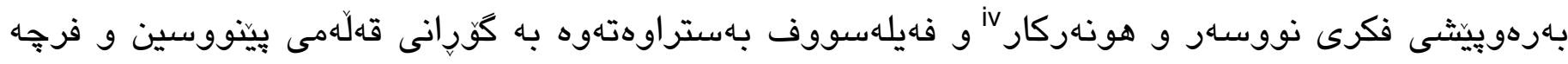
و رهنگ و تهوش و بهردى هـيكهلتراشى و كاغهز و مـرهكهبهوه؟" (محهمهد، مـسعوود 19VV، ل بr). له

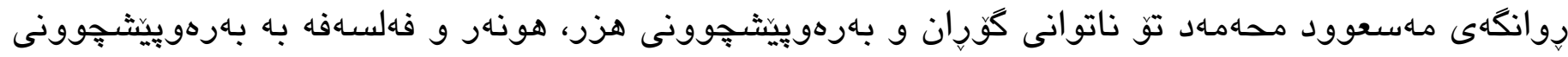

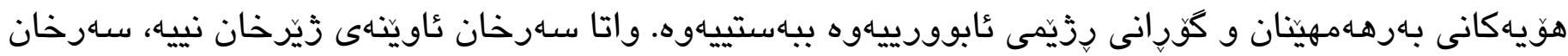

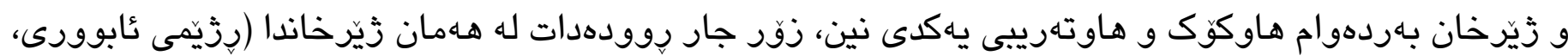

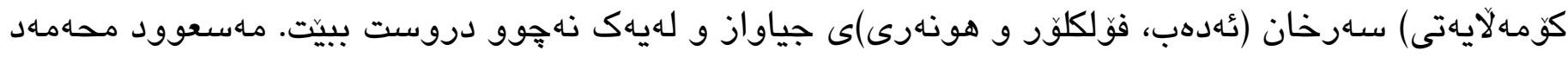

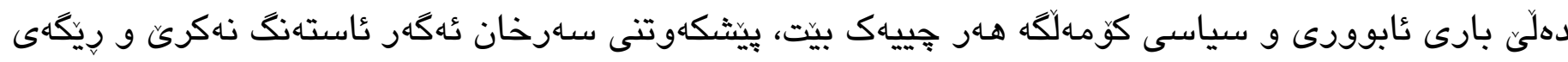

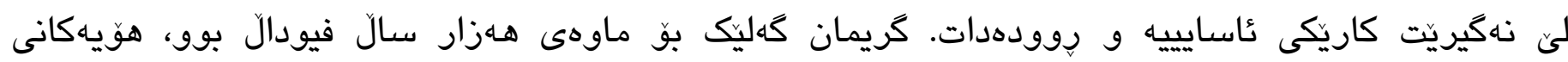

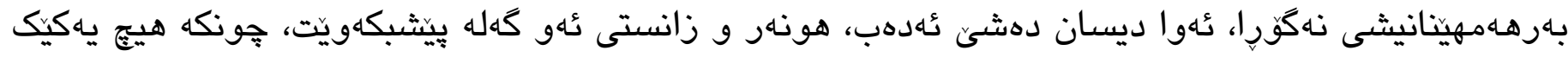

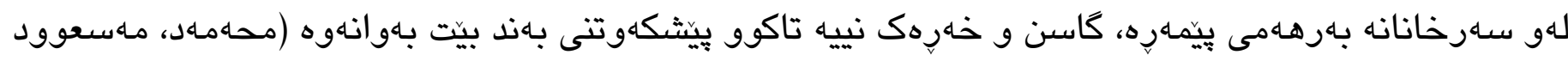
(OV J.r.

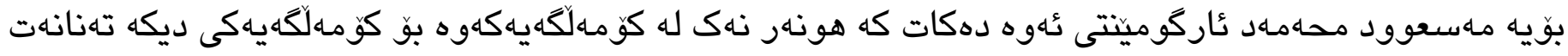

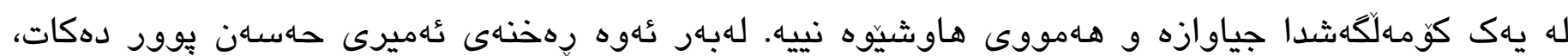

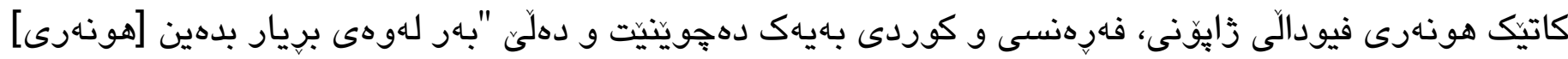

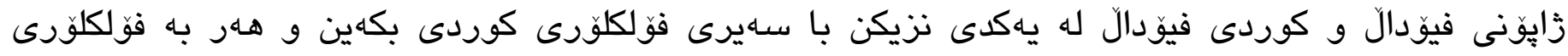

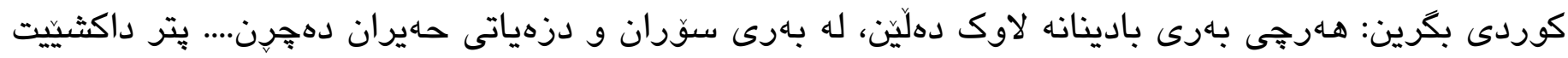

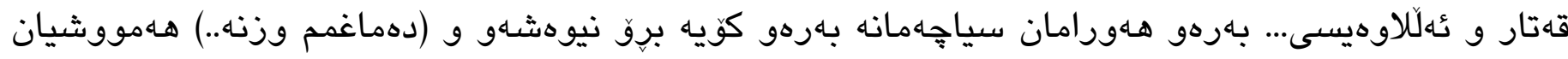

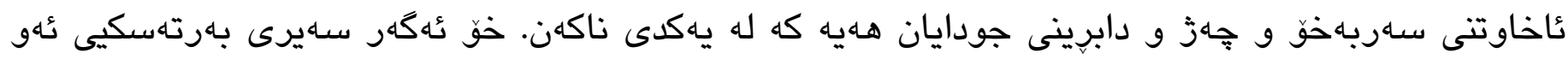

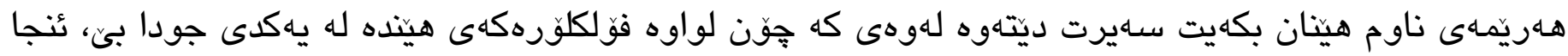

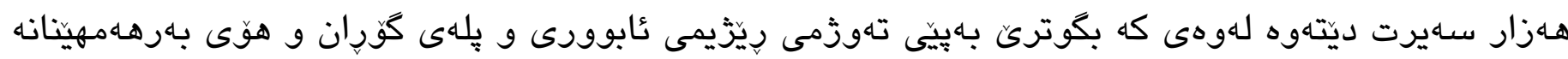


دهبيّ هونهرى كورد و زايقّن له يهكدى بكهن هـار جونكه هـاردوويان فيوّدالن وهيا سـرمايهدارن. هونهرى

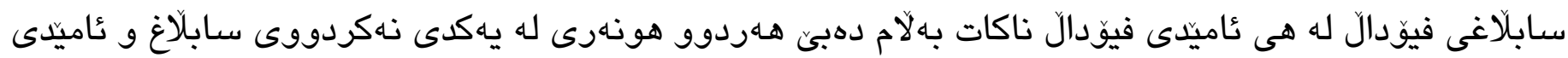

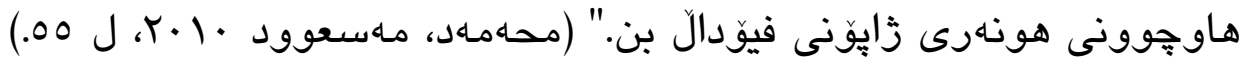

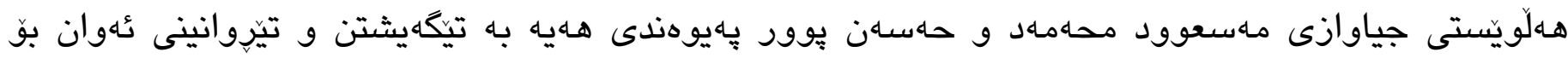

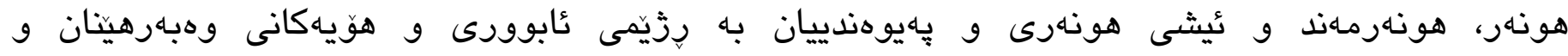
سـارخان/خّرخان. حهسـن يوور له روانكاهيهى ماركسيستانهوه سـيرى هونهر دهكات، له لايهكهوه هونهر

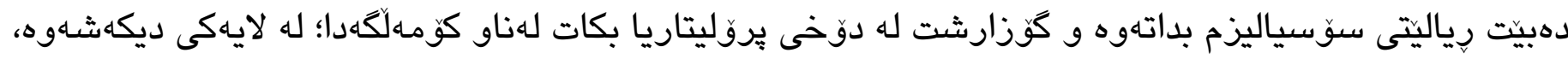

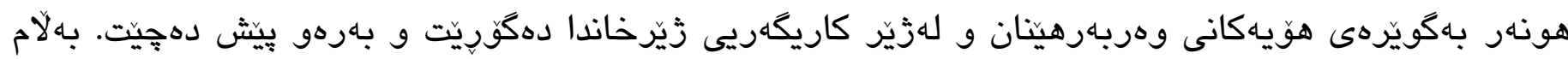

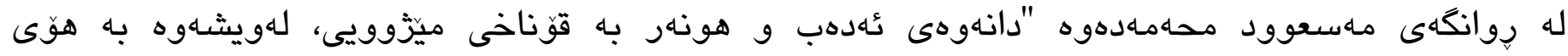

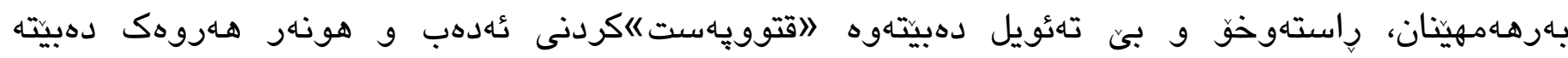

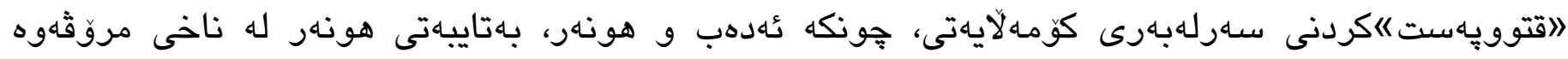

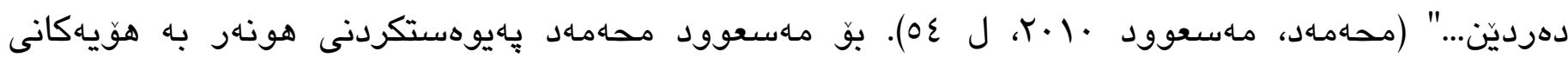

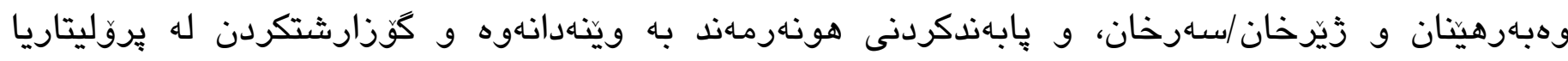

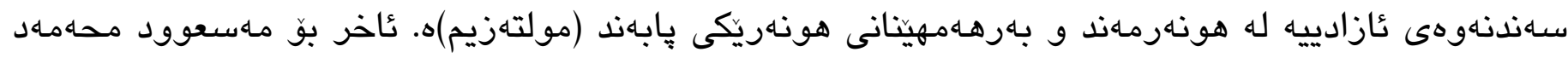
هونهر له ناخى هونهرماهندهوه ديتهكَّريّ، نهك له رياليتى دهرهكييهوه. جهونكه هونهر كوَيى و لاساييى داكهوت (واقع) نييه، بهلكو كُوزارشت له خودى هونهرماند دهكات. بوّيه "هونهركار يتر ... قهرزدارى زاتى خوّيهتى لهو

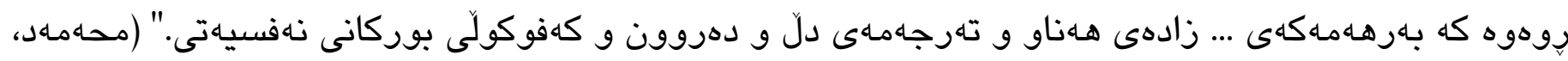

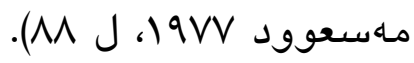

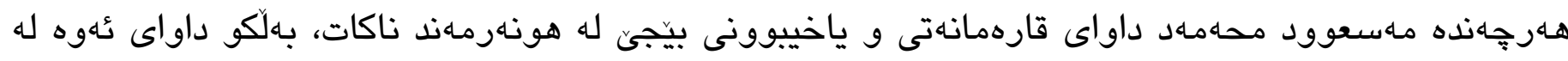

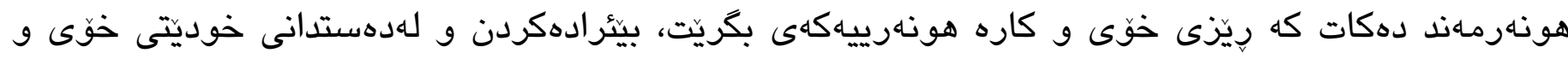

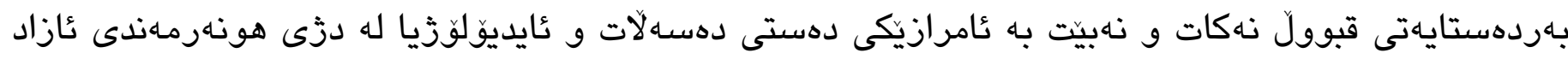

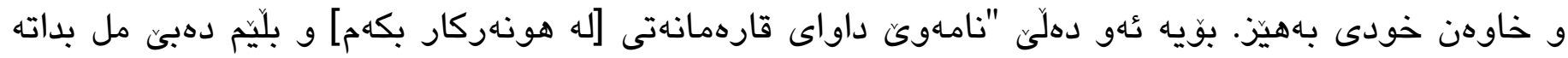

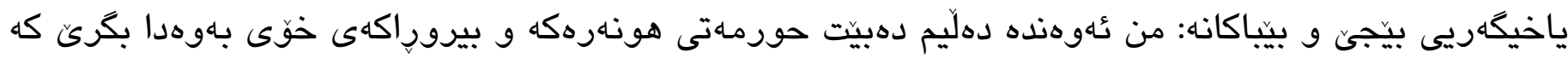

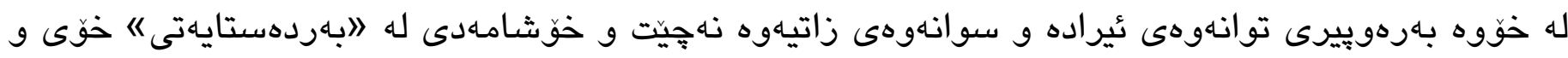

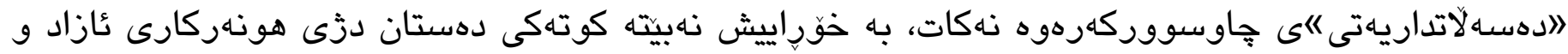

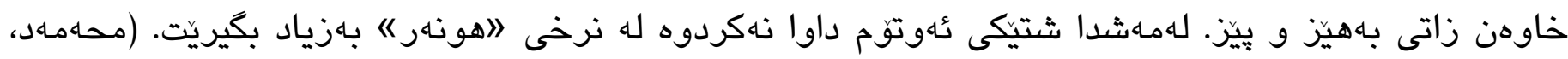

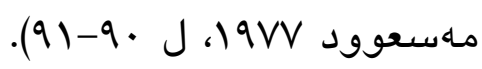

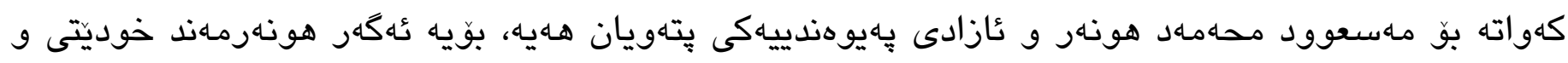
سهاربهخوّيى خوّى للدهستدا، ئهوا خُوى و هونهرهكهشى نابووت دهبن. 


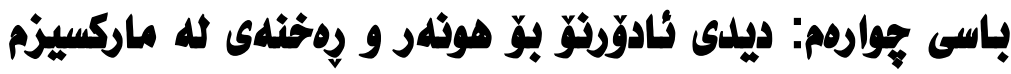

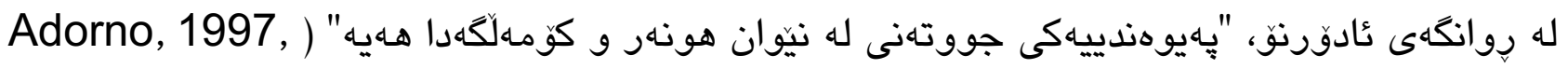

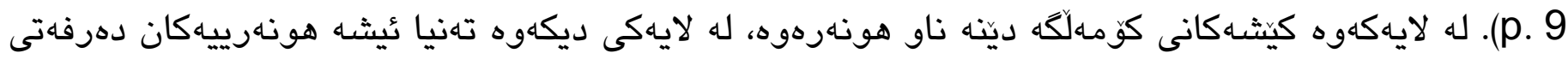

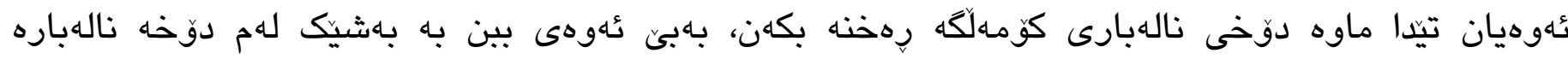

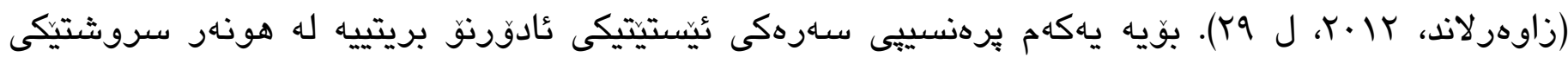

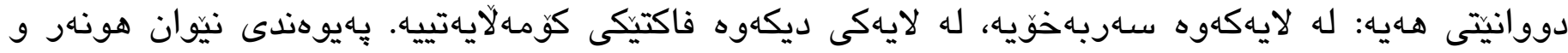

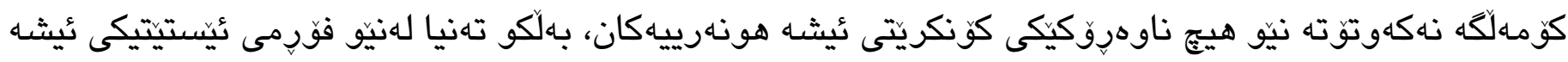

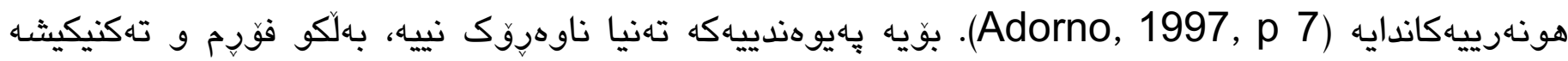

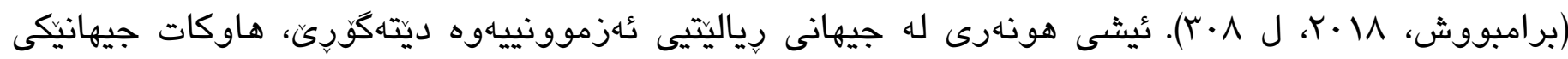

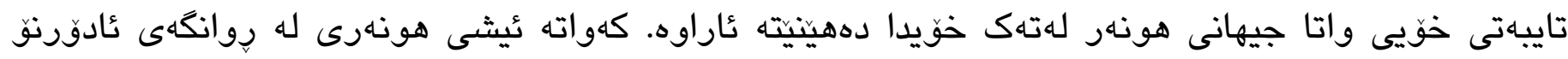

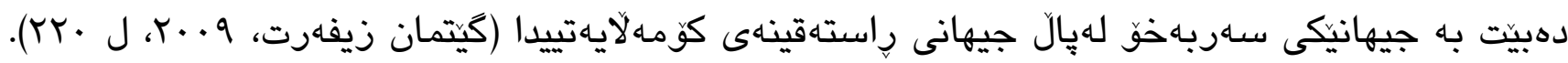

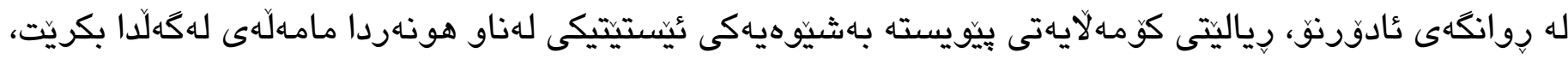

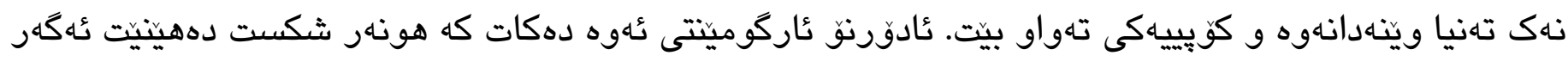

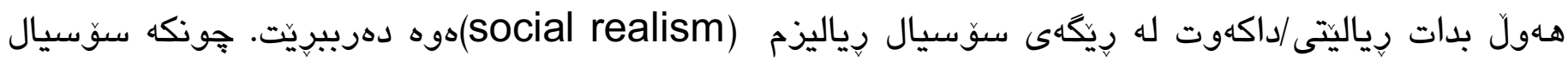

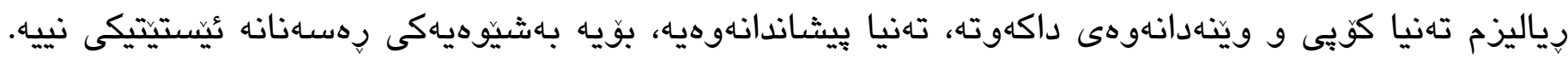

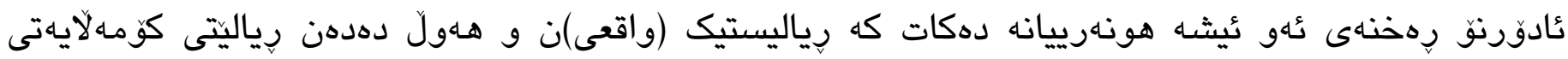

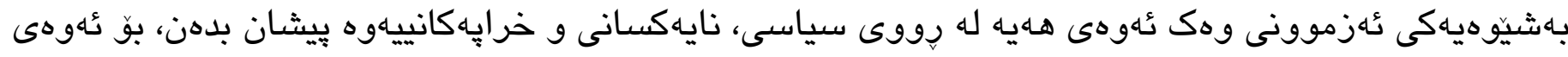

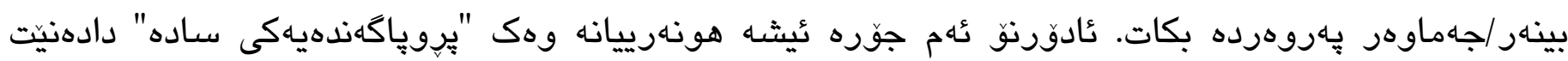

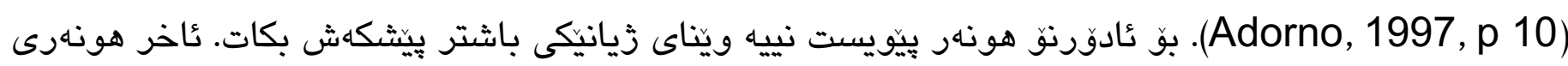

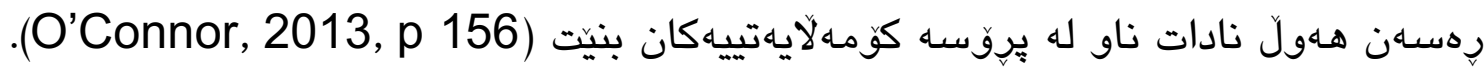

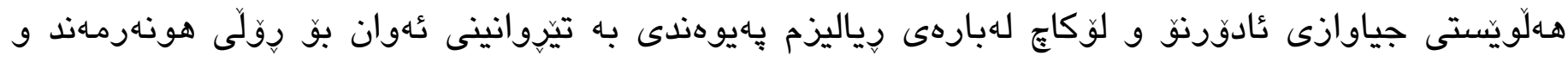

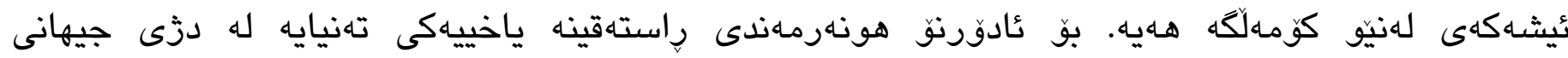

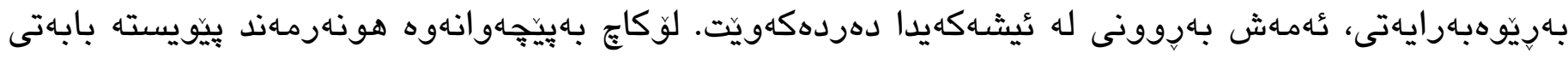

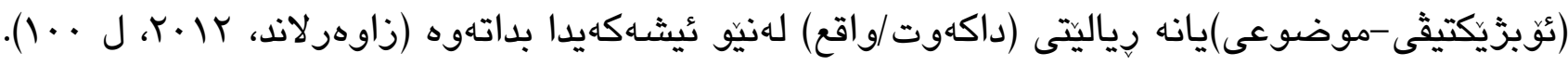




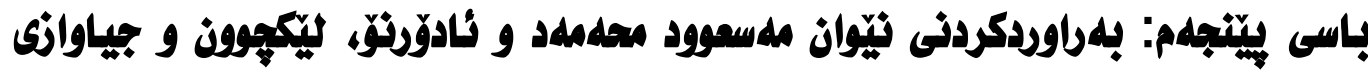

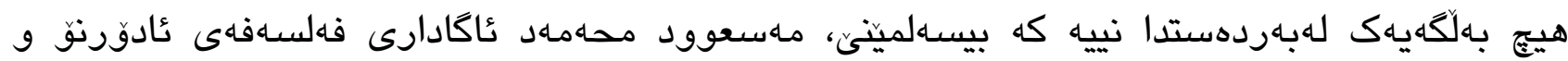

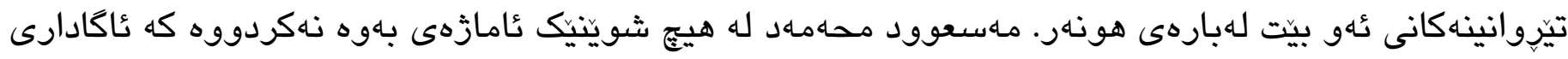

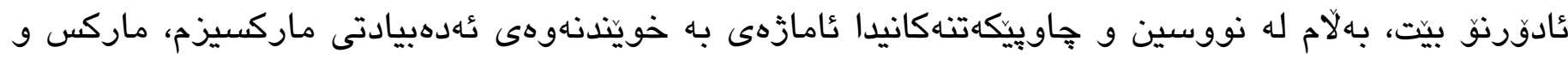

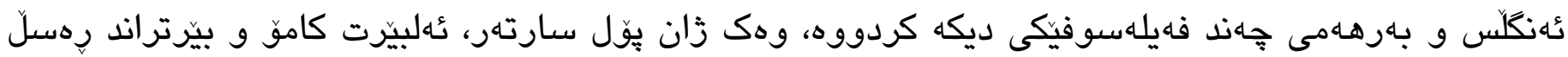

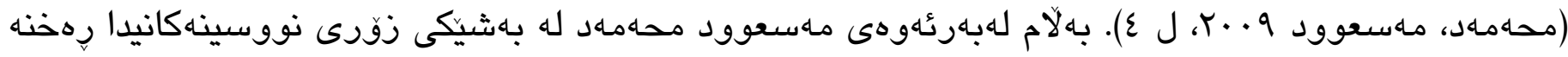

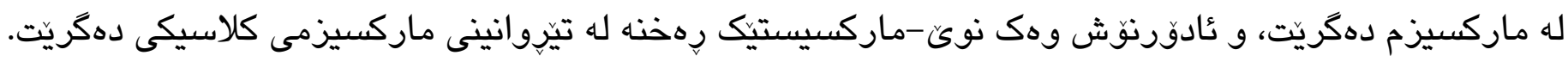

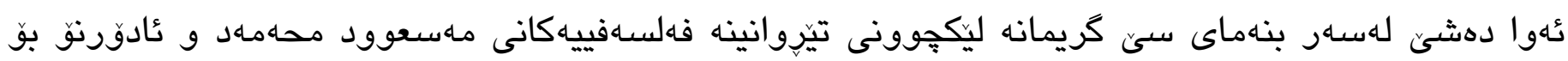
هونهر باس بكهين. يـكهم، هـردووكيان يّتى دهرجوونيان رهخنهكردنى تيوّريى ماركسيزمه بو هونهر. دووهم،

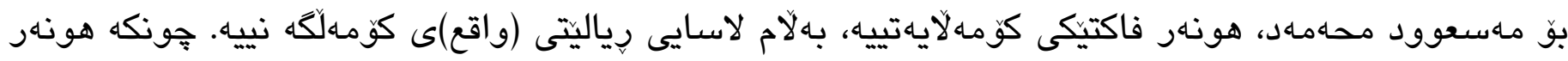

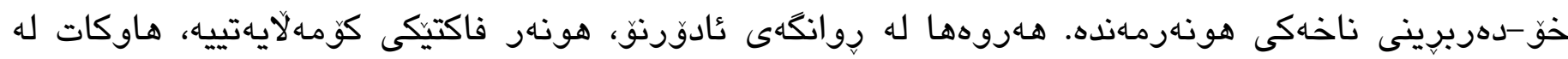

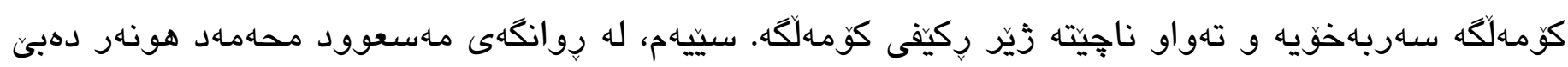

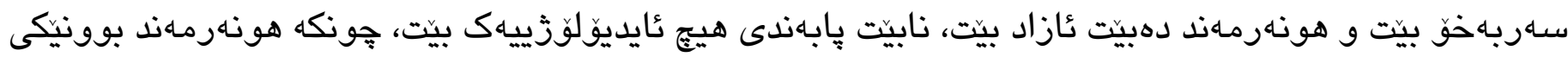

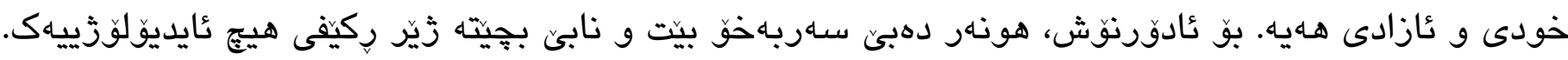

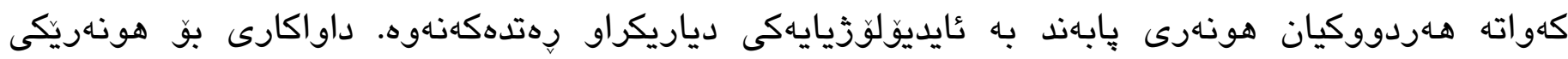
سهاربهخو و عَازاد بـرز دهكهنهوه.

ينتى دهرجوون و دهستيّكى تيوّريى هونهارى ماهعوود محهماه و ئادورنق بريتييه له رهخنهى تيوّريى

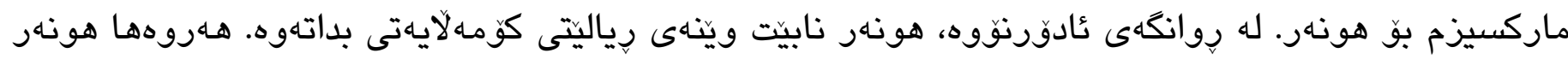

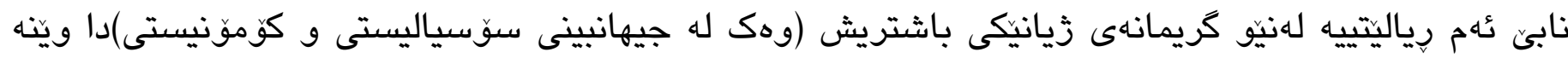

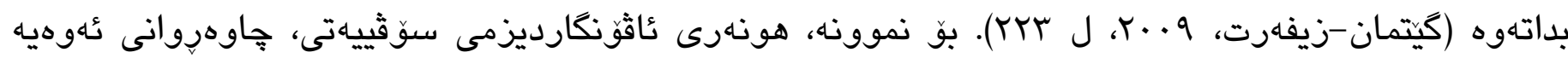

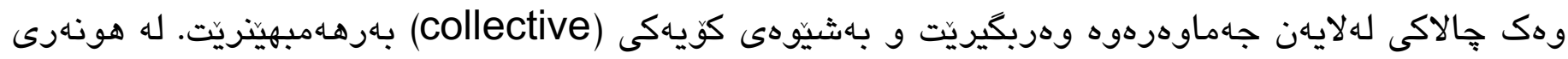

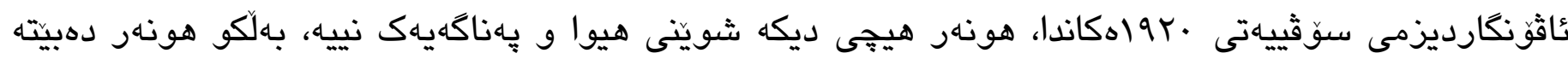

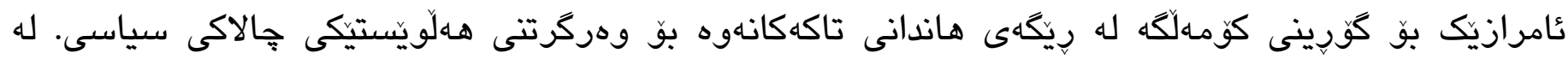

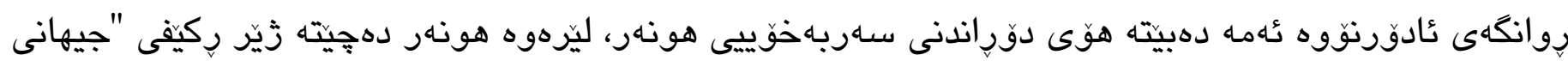

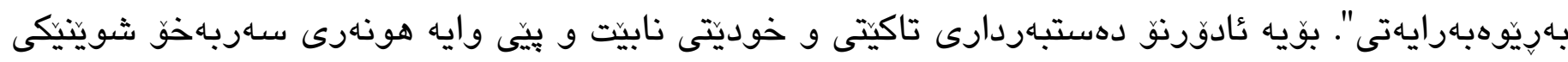

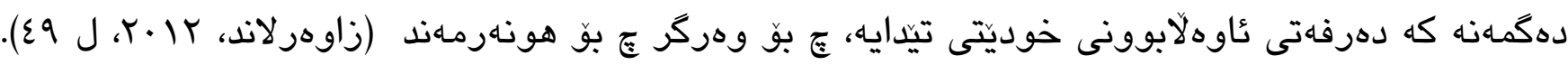

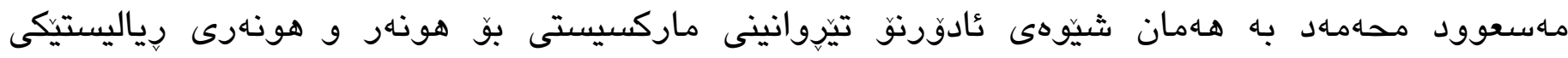

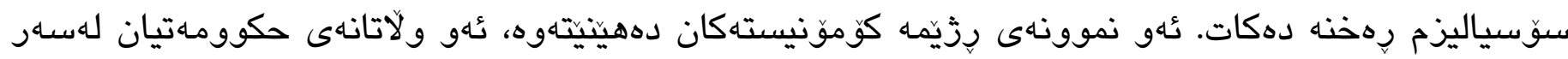

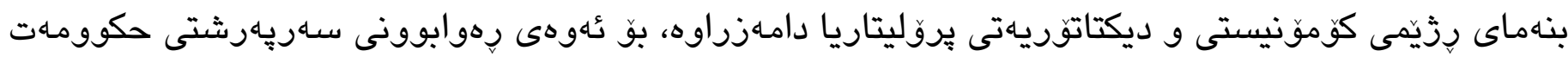




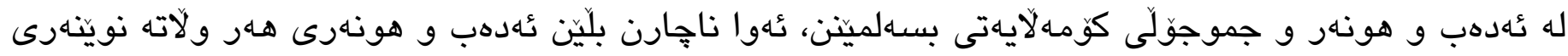

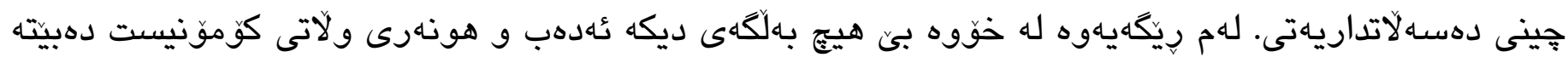
نويناهرى داخوازييهكانى جينى يروّليتاريا، ئهدهب و هونهرى سـهرمايهداريش دهبيته خزماهتكارى سـاهمايه. لهبهر

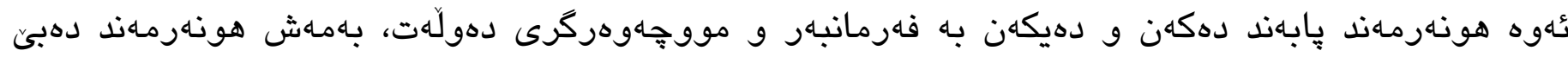
لهسهار داواكارى رِّيّم كار بكات و بهردهستايهتى قبوول بكات. "له رِّيّمى كوموّنيستدا تُهديب و هونهركار فهرمانبهر و مووجها خورى حكوومهتن و لهوانهيه به لاامر ادارى" كوتار بنووسن وهيا تهمسيل رِيكبيخن ". بوّيه

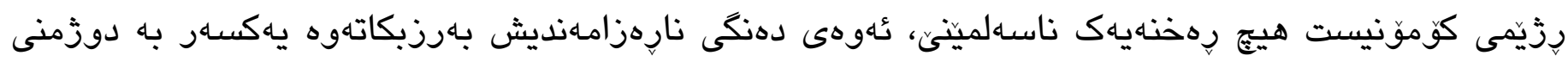

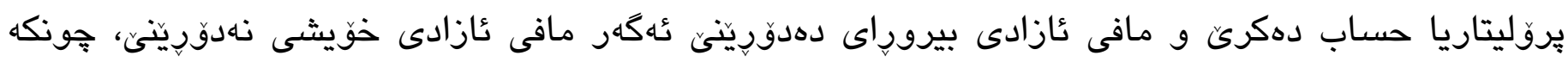

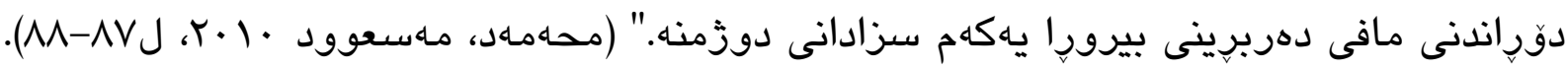

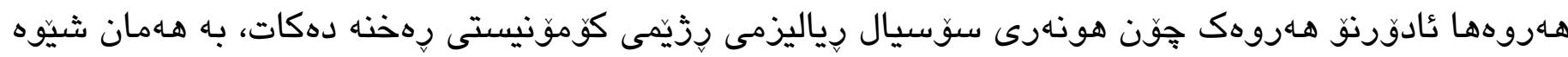

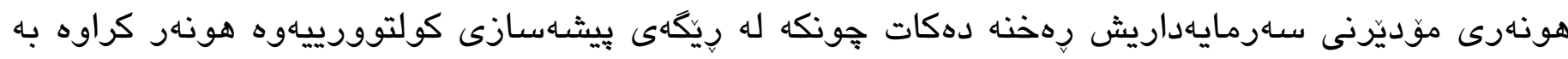

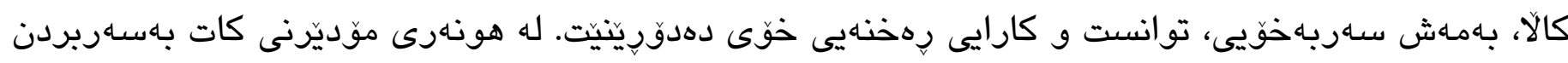

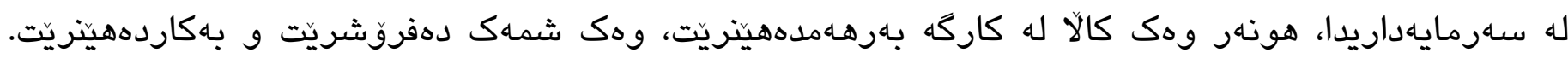

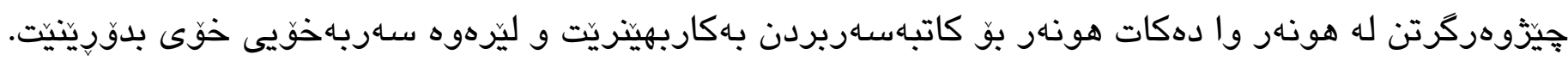

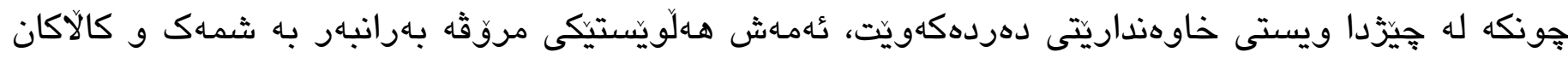

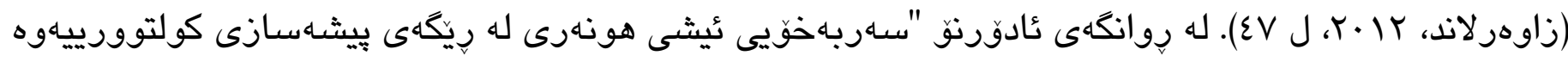

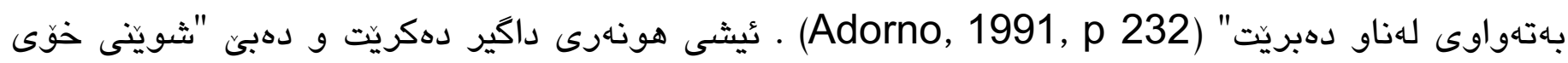
لهناو شمهك و كالآكاندا بكريت كه ئامادهن بوّ بهكارهينان" (Adorno, 2002, P 127).

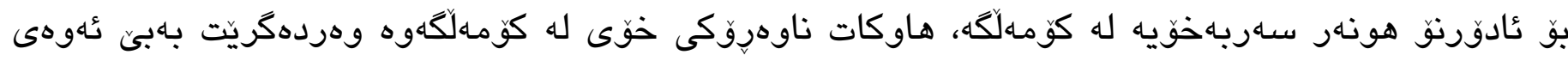

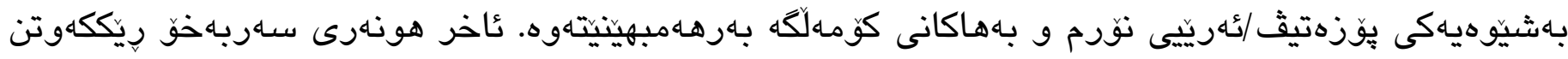

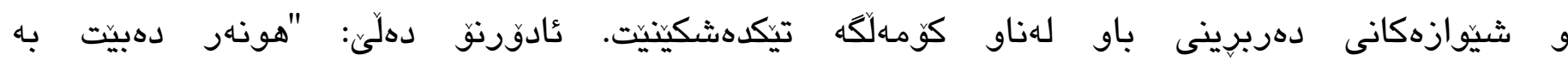

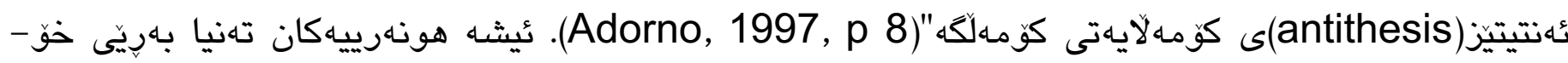

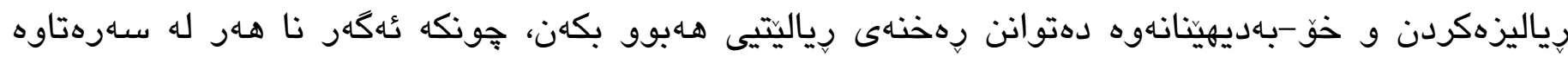

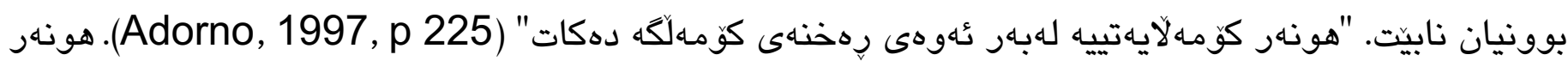

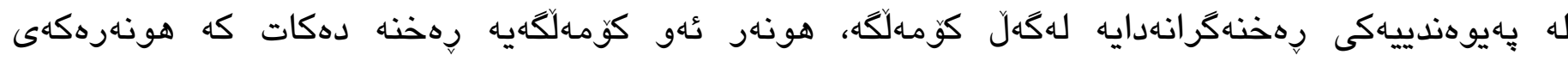

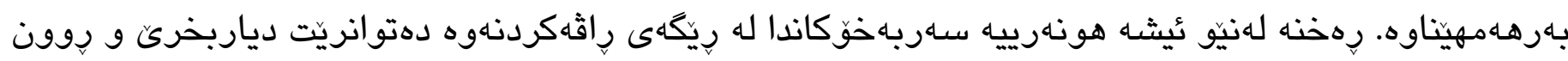
بكرينّهوه (O’Connor, 2013, p179).

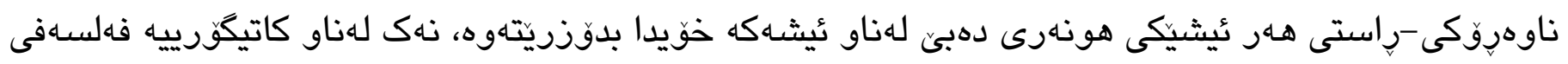

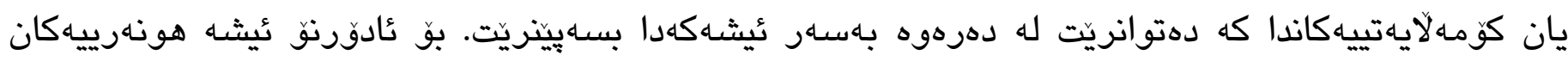




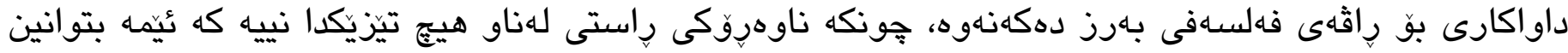

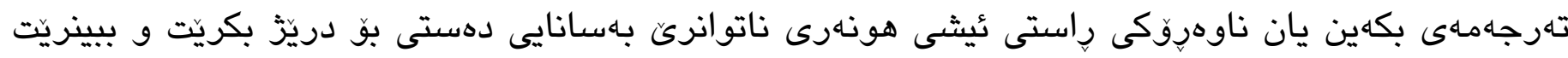

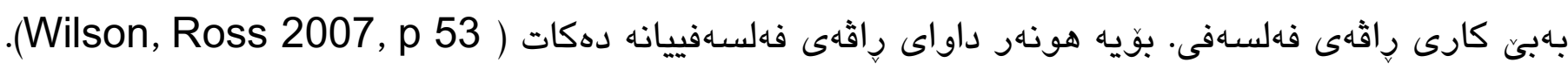

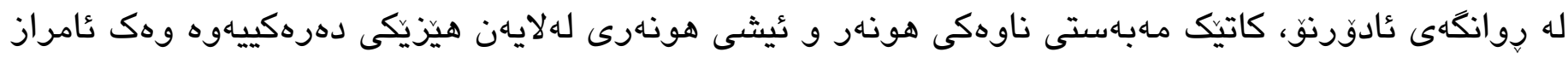

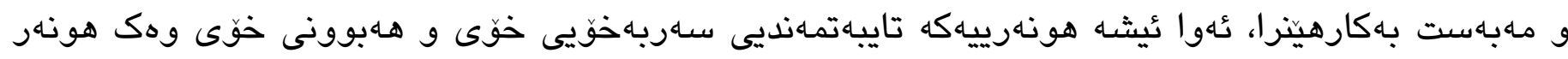

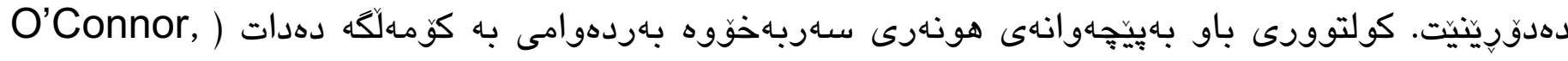

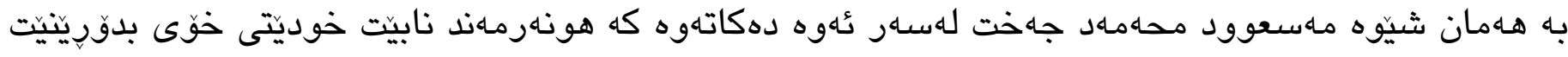

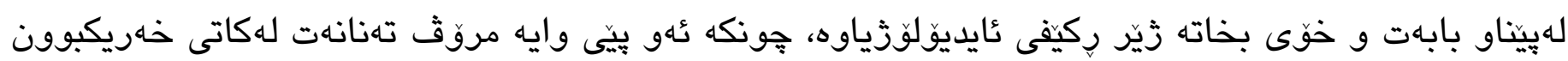
به بابهتيش هـهر بوونهوهريكى خودييه. لهبهر عُهوهى مروق هوَش و سيرادهى هـهيه و جياوازه له بوونهوهرهكانى ديكه. هونهرمـانديش له مروّانى ديكه زياتر خودييه و خودهكى لهناو هونهردا عاوهلا دهبيت، بوّيه نابيت لهبهر

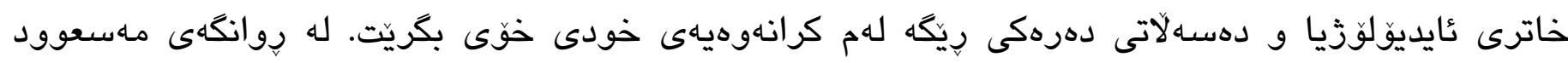

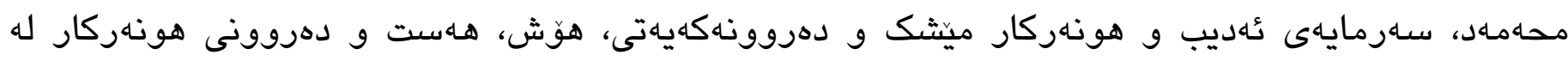

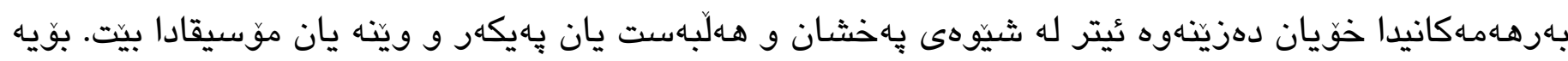

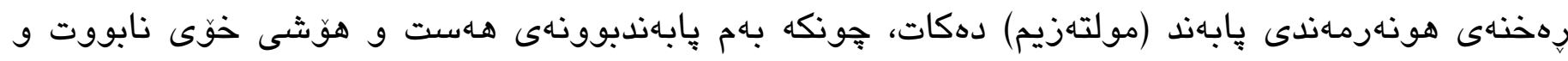
نهزوّى دهكات. "له كُّشهى نهزهرى ئيلتزامى هونهركارهوه دهبيَ هونهركار يهكجار بهدرهنكهوه بيته سهار لهدهستدانى خوى و يرِكردنهوهى دهروونى به بابهتى خوازرايهوه و بهديارى وهركيراو جونكه لهوهدا ئهو بهر

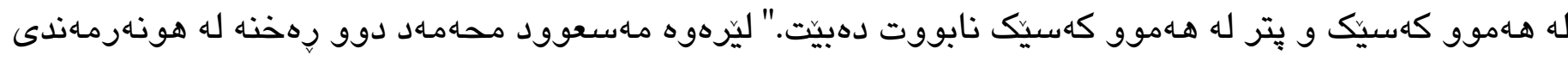

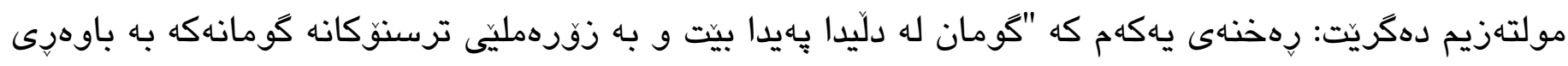

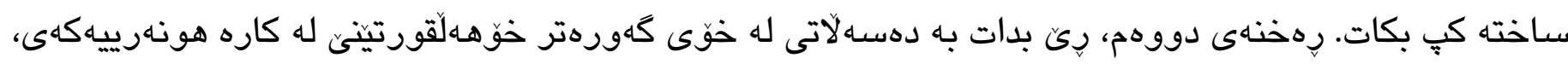

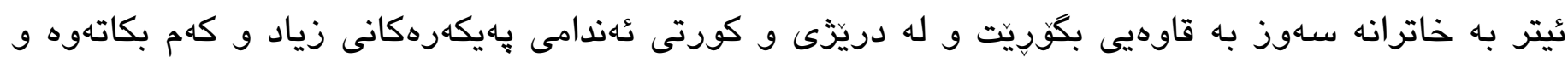

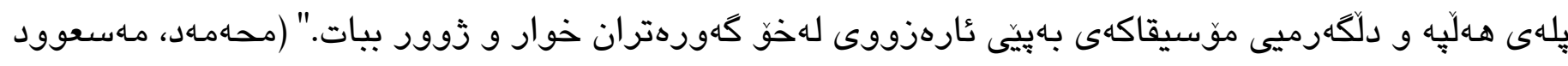
.$(9) J .19 \mathrm{VV}$

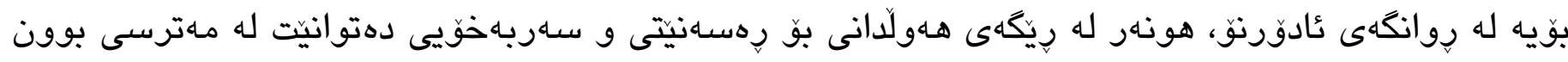

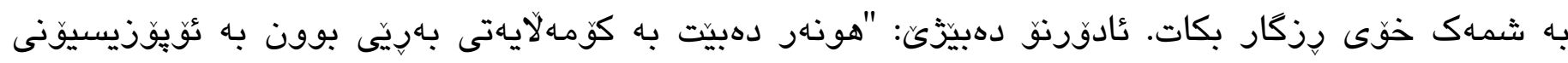

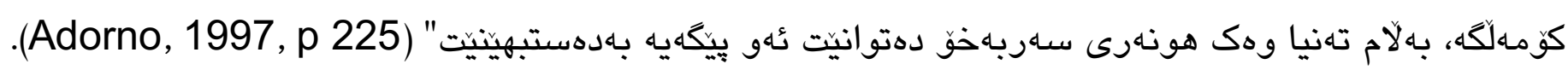
بوّ ثٔادورنو تهنيا هونهرى سهربهخو بهتهواوى ثٔهو كاراييه رهخنهييه كومهلاّيهتييهى هـهيه جونكه هونهرى

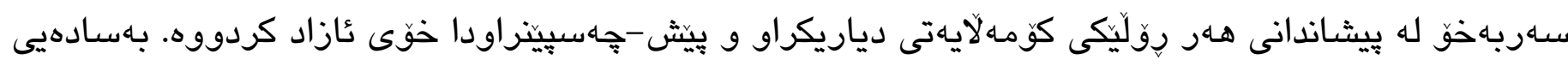

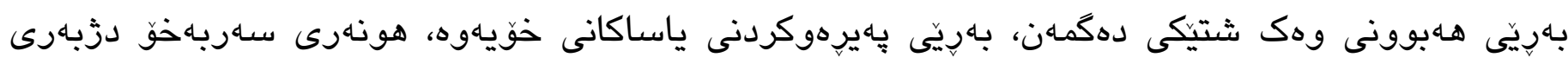




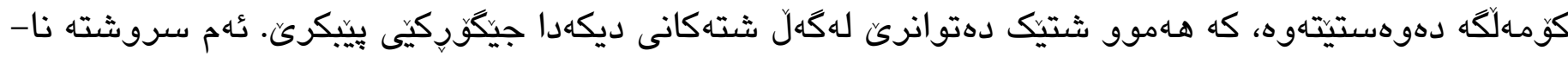

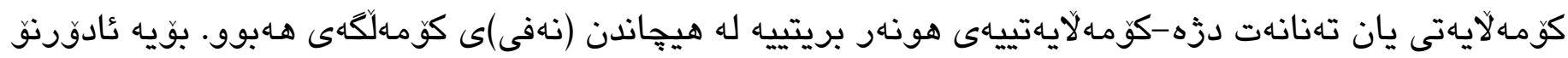
هونهر وهك رهخنهى كوّمالكَه دهبينيت (Wilson, Ross, 2007, p 50).

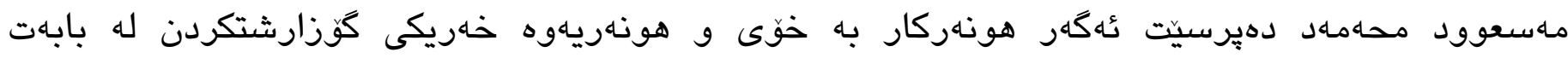

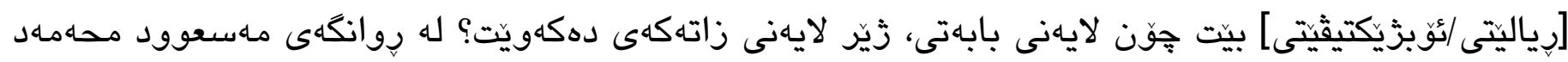
مروق بهكثتى و بهتايبهتى هونهرمـاند تهنانهت لهكاتى خهريكبوونى به بابهات (ماوزوع)يش هـر بوونهوهريكى

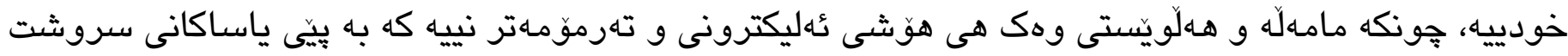
و له شيّوهى ناجهاريدا بيتها دى، تهنانهت وهك هى كيانلهبهرهكانى ديكهش نييه كه له ريّى رهماه و غهريزهى

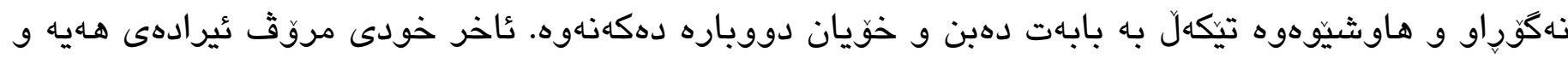

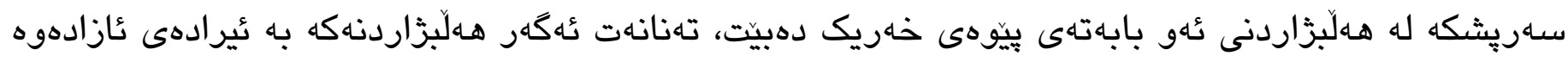

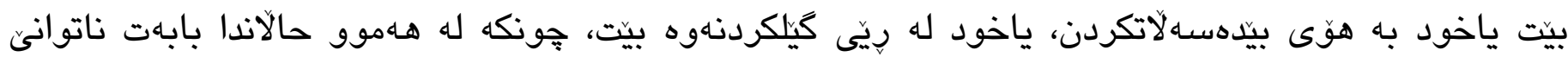

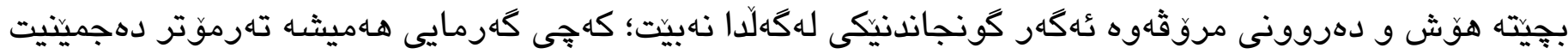

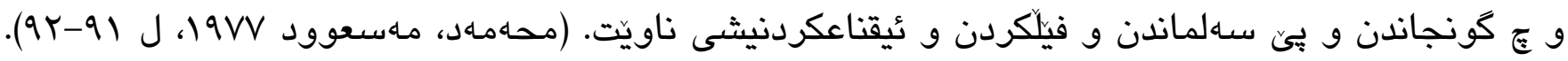

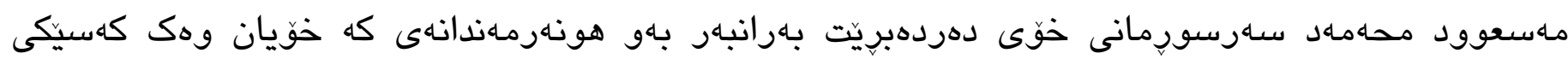

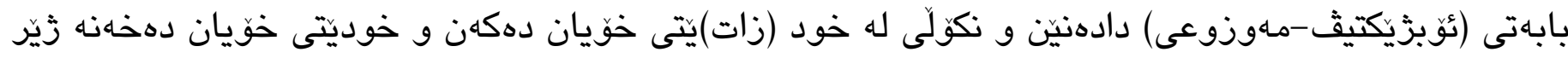

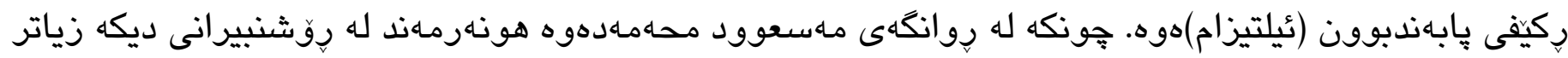
كهسيكى خودييه، بوّيه جهخت لهسهار ئهوه دهكاتهوه هونهرمهاند نابيت خوديتيى خِىى لهدهستبدات، يان زور

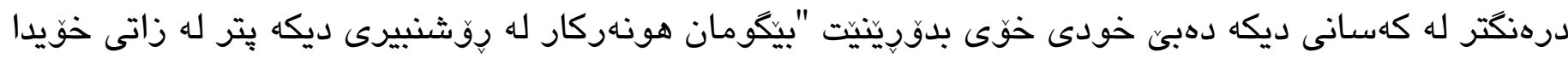

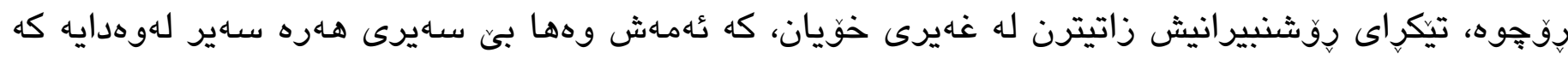

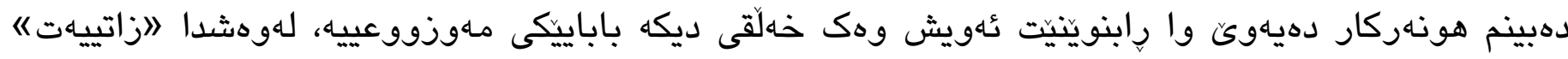

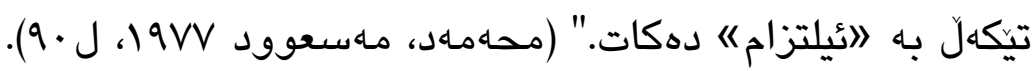

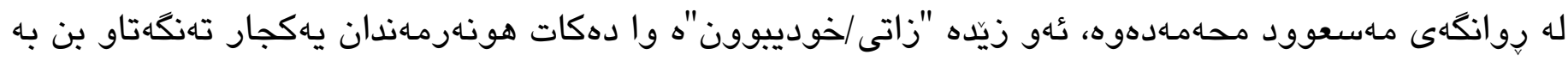

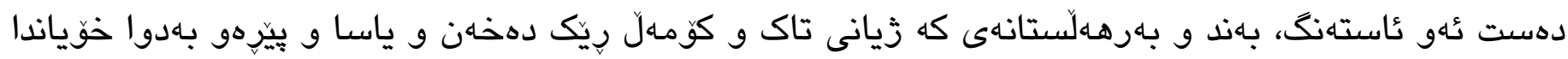

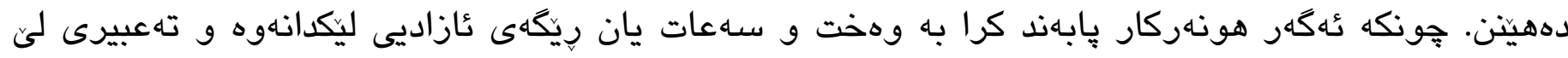

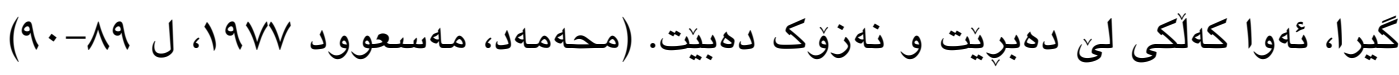

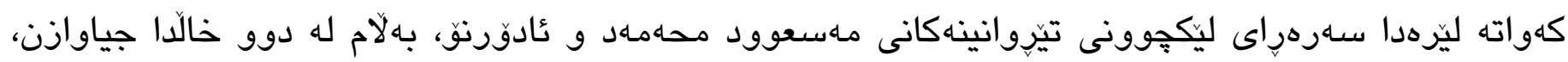

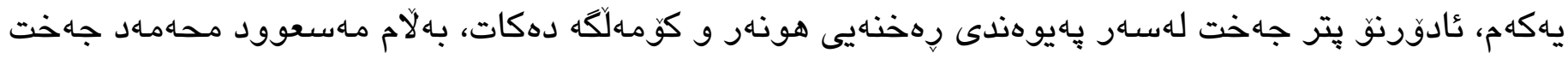

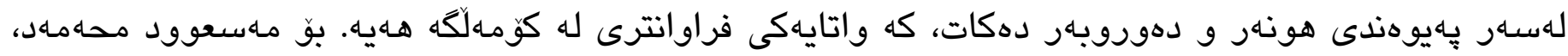
هونهر بهرهـهى هوَش و سوّزى خودى هونهرمهنده يهايوهست به دهوروبهر، "دهوروبهريش وهها فرهوانه، 
بريتييه له سروشت و هـالكاهوتنى ماددى مروقكرد و ميراتى سـاهافى تا دهكاته ثُهو ماموّستاياءى كه به ريّكاهوت

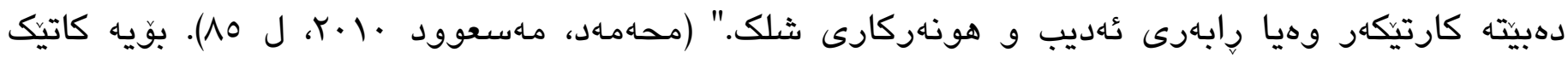
هونهرماند بوون، جيهان، دهوروبهر، سروشت، كومهلكَه دهرك دهكات و ئهزموون دهكات، ئهم ئهزموون و

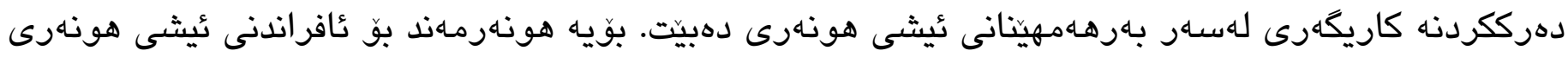

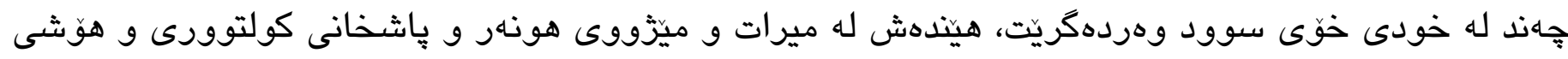

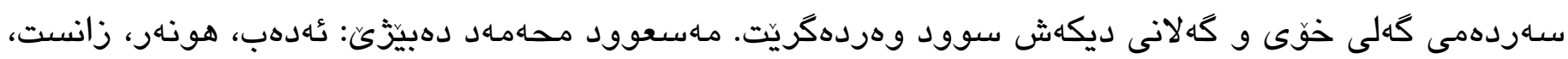

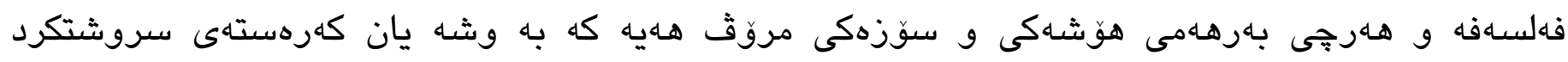

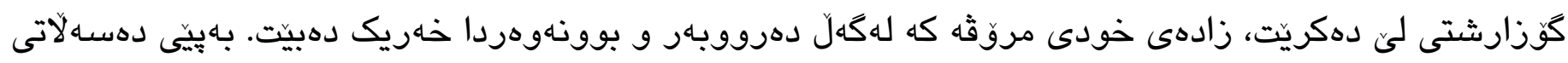

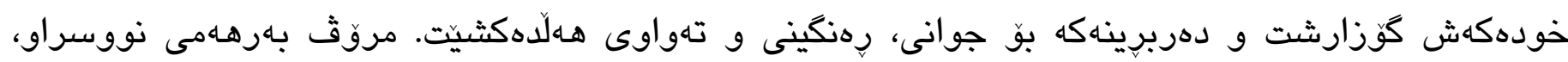
ديتراو و بيسراوى له ثُهدهب، هونهر و لكهكانى ديكهى زانيار (مهعريفه)دا يشتاويشت به ميرات بّو به بيّدهمينيت.

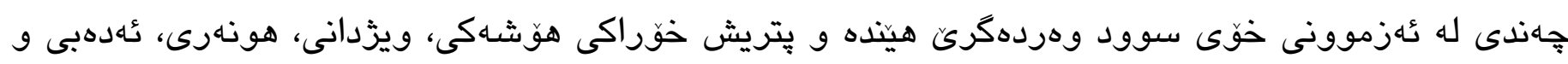

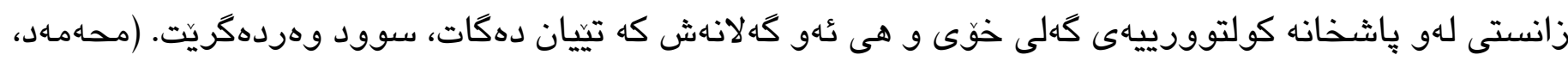

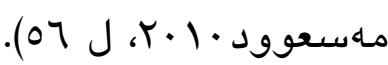

دووهم، مهسعوود محهمهد و ئادورنق سـارهراى ئهوهى هـاردووكيان هونهر وهك فاكتيكى كومهلآيهتى دهبينن، باهلام بوّ مـسعوود محهمهد هونهر له لايهكى ديكهشهوه بهرهـهى خودى هونهرمهنده. واتا ئيشى هونهرى

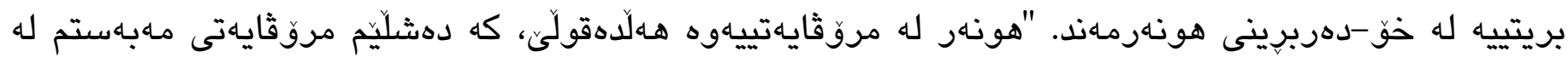

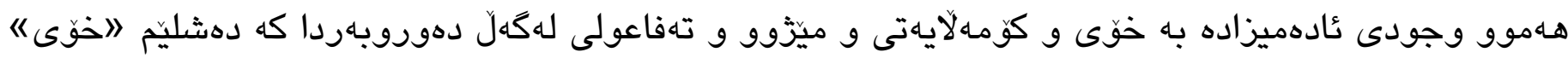

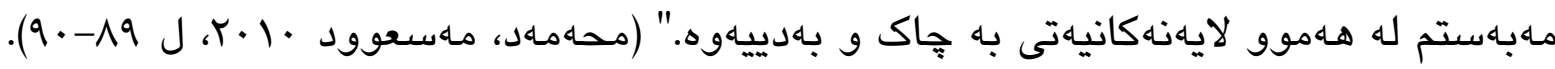


له ئهنجامى ئهم تويَّزينهوهيهدا، بوّمان دهردككهويت كه سهرهراى ئهوهى مـسعوود محهمهد و تيوّدور

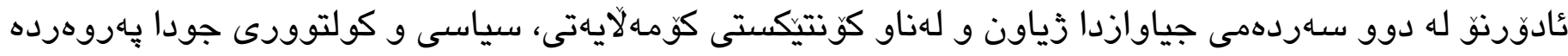

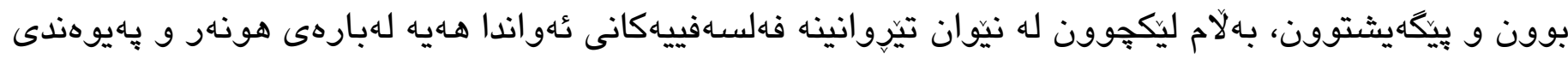

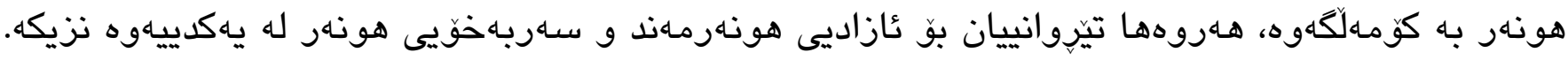

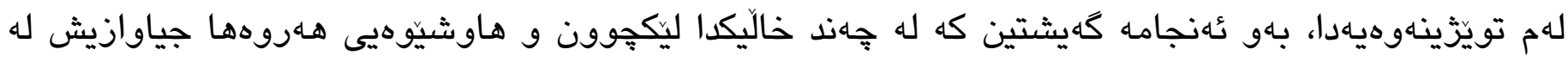
نيّوان تيّروانينه فهلسهفييهكانى مهسعوود محهمهد و ئادورنو لهبارهى هونهر هـيها.

يهكهم، هاردووكيان خالّى دهستينيكى تيوّرييهكانيان بريتييه له رهخنهكردنى تيوريى ماركسيزم بو هونهر و به

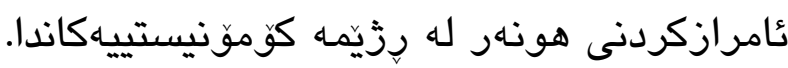

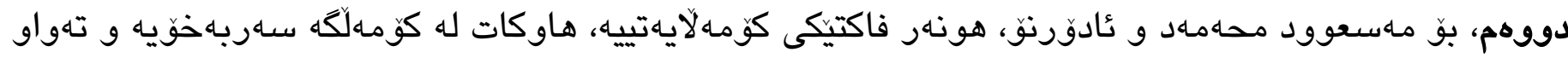

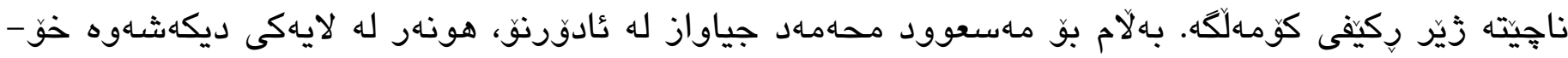
دهربرينى ناخهكى هونارمانده و ئيشى هونهرى زادهى خودى هونهرمهنده.

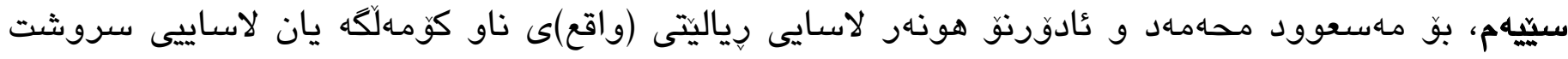
نييه.

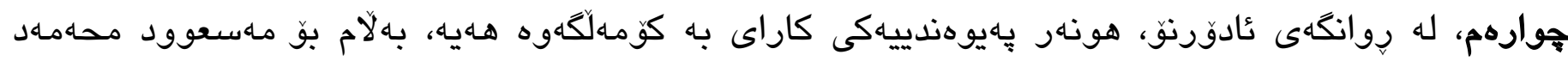

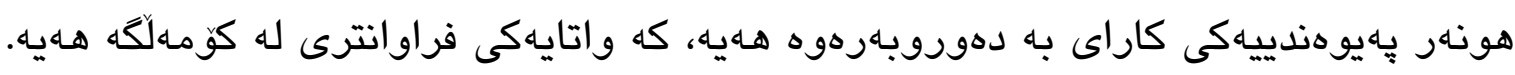

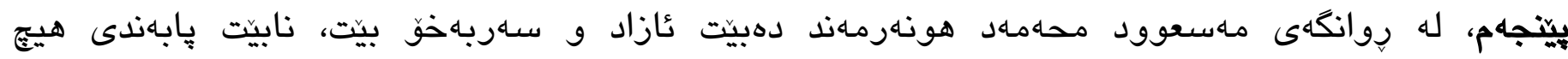

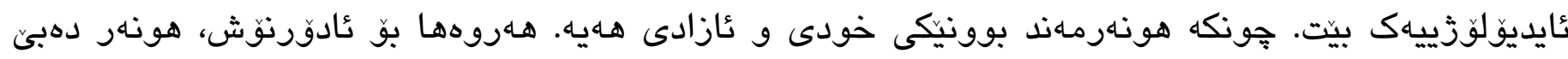

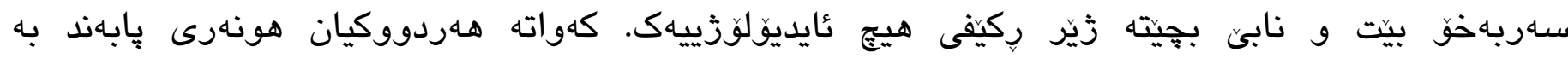

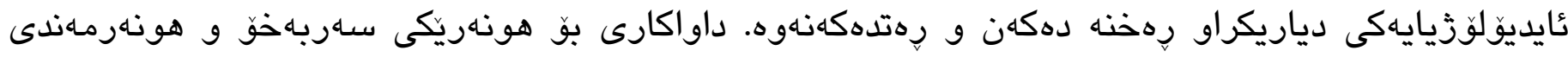

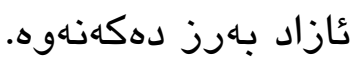




\title{
Masoud Muhammad and Theodor Adorno on Art: A Comparative Study
}

\author{
Nabaz Samad Ahmed \\ Department of Plastic Arts, College of Fine Arts, University of Sulaimani, Sulaimani, \\ Kurdistan Region, Iraq. \\ E-mail: nabaz.ahmed@univsul.edu.iq
}

\begin{abstract}
:
A comparative analysis of two great thinkers who are placed in different geographical, social, cultural, and intellectual contexts is a difficult task. Masoud Muhammad a Kurdish Philosopher and Theodor Adorno, a German philosopher, are belonging to two different cultural and intellectual traditions but it can be argued that the core of their philosophical views and analysis on art are thematically connected and astoundingly close. Muhammad and Adorno are doing the same thing, but at a different level, context, and different methods regarding art. They both lived during the dark times of totalitarian regimes: Nazism and Ba'athism in Germany and Iraq respectively. In this paper, I will propose to show that it is possible to establish similarities between the philosophical views of these two thinkers based on three presuppositions. First, both Masoud Muhammad and Adorno's point of departure is the criticizing Marxist art theory. Second, for Muhammad art is a social fact, and not an imitation of society's reality, since art is the self-expression of the artist; Also for Adorno art is a social fact and in the meantime, it is independent from society. Third, in Muhammad's view, art is autonomous and free; therefore it would not be affiliated with any ideologies. In the same manner, Adorno argues that art is autonomous and critical to society. The forgoing illustrated that these three presuppositions set the tone for the theme and hypothesis of this paper. The main goal of this paper is to examine the similarities between Adorno and Muhammad's philosophical views concerning art.
\end{abstract}

Keywords: Maxism, Art and Society, Autonomous Art. 


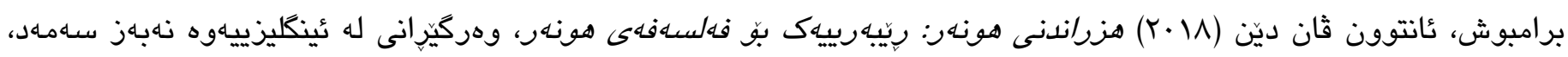
هيوا فاوندهيشن، سليمانى.

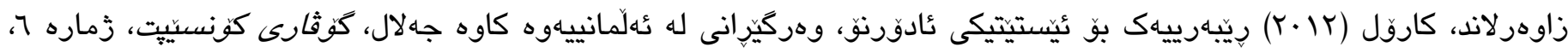

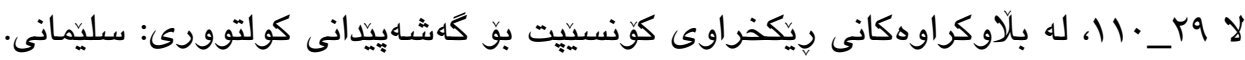

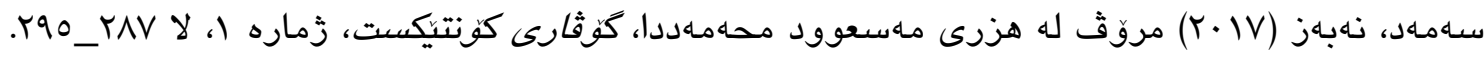

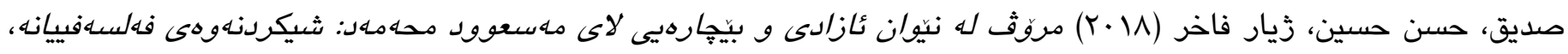

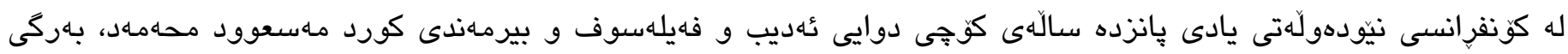

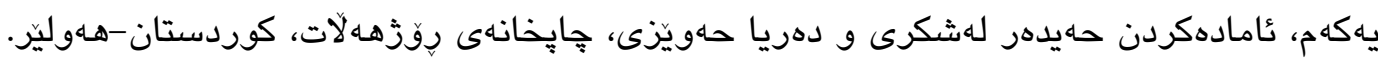

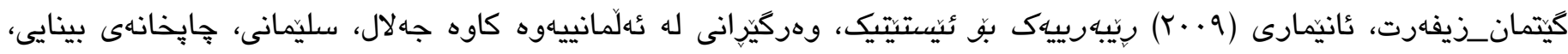
بهاِيَوهبهريتيى جاب و بلأوكردنهوهى سليمانى.

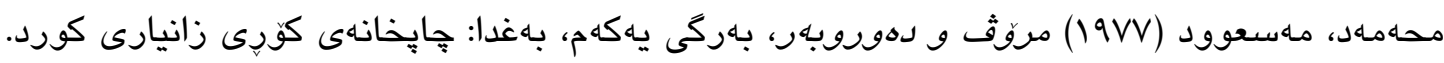

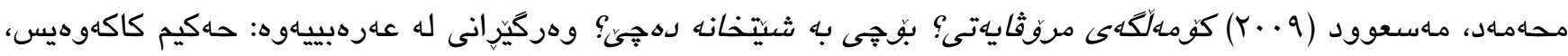

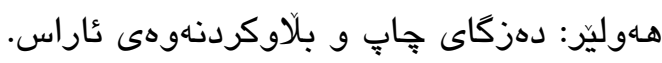

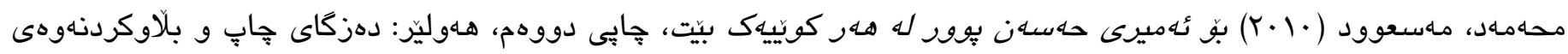
عاراس. - ماس.

Adorno, Theodor W. (1997) Aesthetic Theory, London: Continuum.

Adorno, Theodor W (1991) The Culture Industury: Selected Essays on Mass Culture, London: Routledge.

Adorno and Max Horkheimer (2002) Dialectic of Enlightenment, Stanford, California: Stanford University Press.

Lukács, Georg (1962) The meaning of contemporary realism, London: Merlin Press.

O’Connor, Brian (2013) Adorno, London: Routledge.

Wilson, Ross (2007) Theodor Adorno, London: Routledge. 
أ . مهسعوود محهمهد سالّى 1919 له كويهى باشوورى كوردستان هاتوته دونيا. له شارى بهغدا سالّى

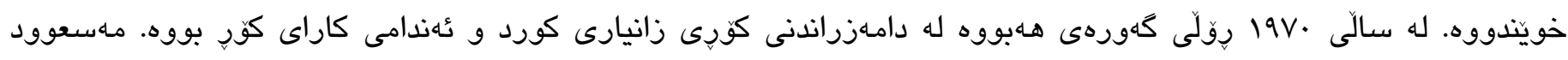

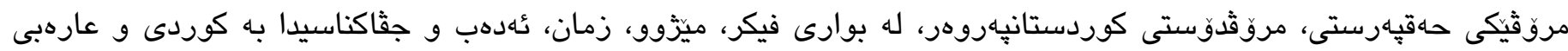

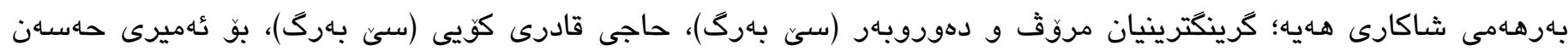

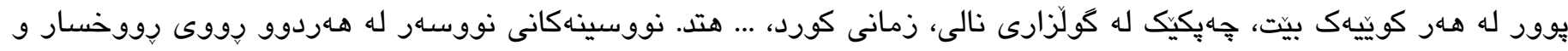

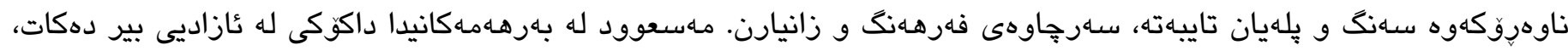

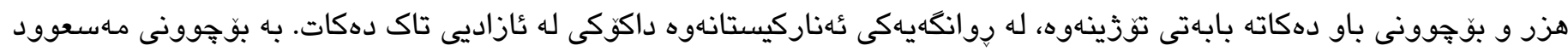

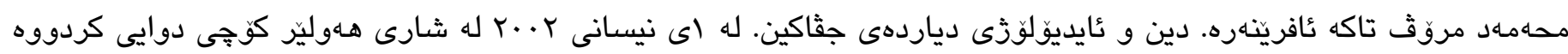

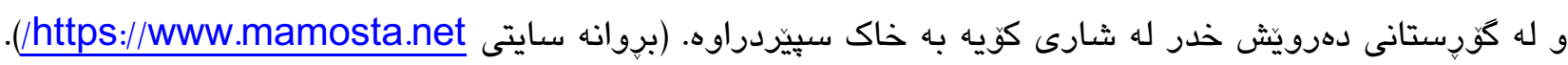

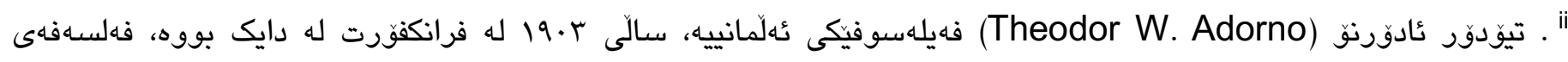

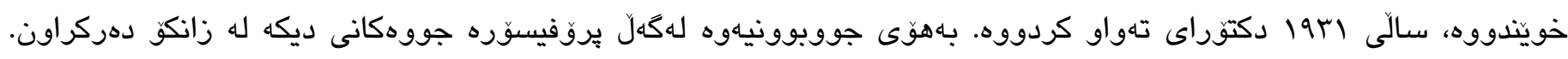

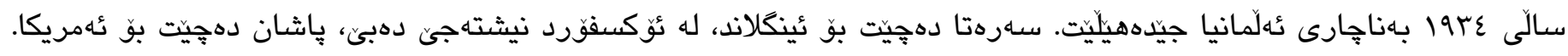

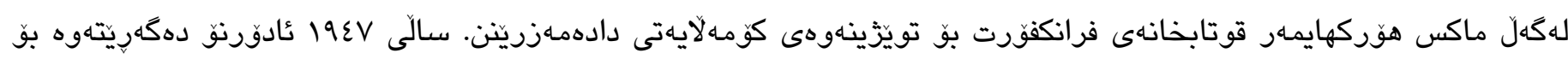

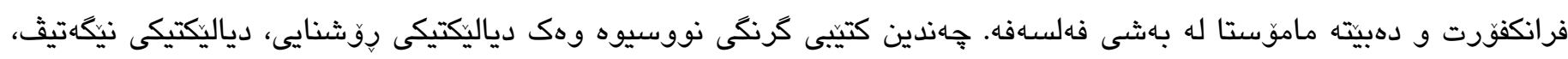

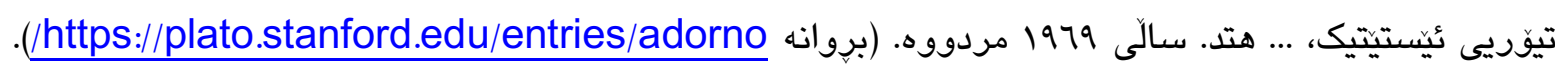

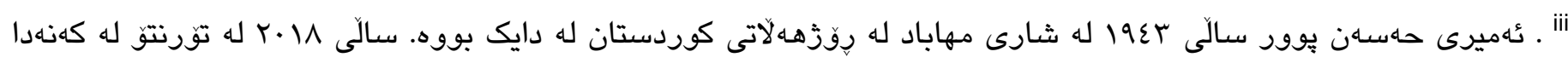

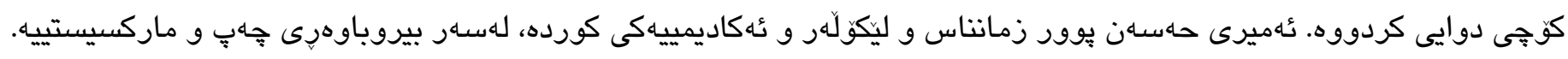

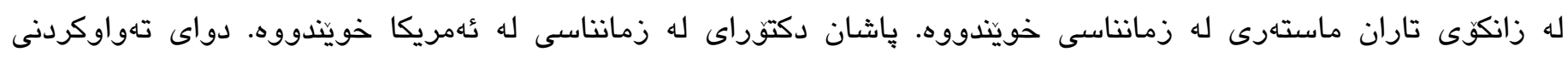

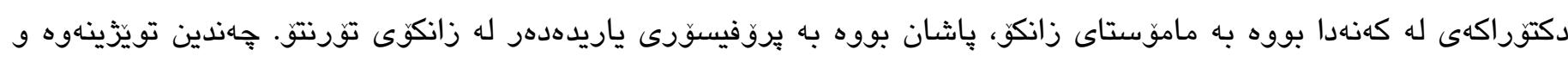

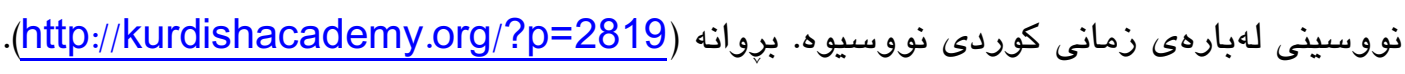

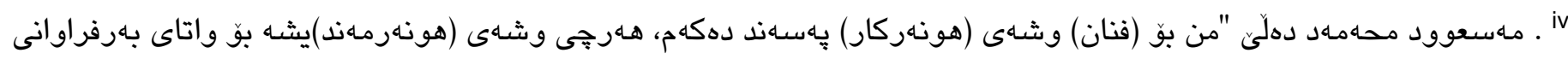

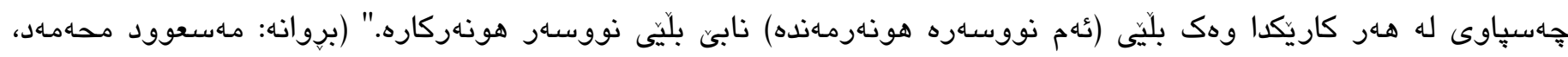

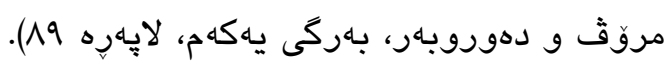

